\title{
DO FDI AND PATENTS DRIVE SOPHISTICATION OF EXPORTS? A PANEL DATA APPROACH*
}

\author{
Seren Ozsoy ${ }^{\mathrm{D}}$, Burcu Fazlioglu ${ }^{\mathrm{b}}$ (D), Sinan Esen ${ }^{\mathrm{c}}$
}

\begin{abstract}
This paper investigates whether inflows of FDI and innovative activities act as a channel of knowledge spillovers in improving quality of countries' output. In measuring export quality, sophistication of a country's export basket is utilized. Utilizing panel data of countries for the period 2002-2015 and applying GMM methodology, the results indicate that the level of financial development, the quality of human capital and globalization of a country have a determinant role on the relation between knowledge spillover channels and the quality of exports. Patent applications generally positively affect sophistication of exports. FDI serves as a channel for knowledge spillovers to benefit the sophistication level of exports only for developed, more educated, financially developed and globalized countries.
\end{abstract}

Keywords: Knowledge spillovers, sophistication of export, patent applications, FDI JEL Classification: F14, F21, F41, O10, O30

\section{Introduction}

With globalization and the revolutionary developments in information technologies, the knowledge capital has become an important factor for triggering economic development. Countries with higher knowledge accumulation have the ability to produce more specialized and qualified products using advanced technologies. Accordingly, in the last two decades the world has witnessed an increasing interest in the exchange and diffusion of knowledge among countries, namely knowledge spillovers.

\footnotetext{
* This paper is based on the Seren Ozsoy's Master's Thesis, TOBB University of Economics and Technology, 2018.

a Sakarya University, Sakarya Business School, Sakarya, Turkey

b School of Economics and Administrative Sciences, TOBB ETU, Ankara, Turkey

c University of Sakarya Applied Science, School of Applied Sciences, Sakarya, Turkey

Email: serenozsoy@sakarya.edu.tr, bfazlioglu@etu.edu.tr, sinanesen@sakarya.edu.tr
} 
Among the channels creating knowledge spillovers, foreign direct investment (FDI) has received a special attention in the relevant literature (Liu, 2008; Newman et al., 2015). By means of FDI, multinational firms bring expertise, management skills and financial resources to domestic firms and provide access to frontier technologies (Findlay, 1978). On the other hand, the relevant literature highlights the importance of innovation activities in increasing knowledge spillovers (Coe and Helpman, 1995; Jaffe and Trajtenberg, 1999; Fracasso and Marzetti, 2015). Through inputs and outputs of innovation (such as R\&D, patents, product innovation, etc.), knowledge capital can be generated (Zhu and $\mathrm{Fu}, 2013)$, both increasing existing knowledge stock and yielding knowledge diversity. Besides, the presence of FDI may further generate stronger R\&D spillovers and an increase in patent applications. In fact, as Fajgelbaum et al. (2015) claim, the home market can be a determinant of comparative advantage in producing certain types of products which, in conjunction with a non-homothetic structure of demand (e.g., Jaimovich and Merella, 2012), would induce multinational firms to produce the most successful goods among those products in the location where comparative advantage exists. This provides scope for FDI and hence higher R\&D investment and patent applications.

A noticeable body of literature focuses on knowledge spillover gains from FDI and innovation in economic performance of host countries in terms of growth or productivity (Borensztein et al., 1998; Liu, 2008; Liang, 2017). The evidence of FDI on knowledge spillovers is mixed, presenting negative and insignificant effects due to the competition effect on domestic firms (see, e.g., Haddad and Harrison 1993; Liu, 2008) along with positive effects (see Chuang and Lin, 1999; Lee, 2006) due to transfer of advanced technologies. On the other hand, the impact of innovation is generally found to be positive (Jaffe and Trajtenberg, 1999; Meo and Usmani, 2014). Thus far, limited effort has been spent on how FDI and innovation affect the exporting activity of countries. This is contrary to the fact that interacting with multinationals and investing into innovation may affect the export performance of countries by contributing to capital savings, increasing production capacity of the domestic country and bringing about technology diffusion and managerial know-how so that countries export more to existing foreign markets, enter new export markets, start to export new products and export better-quality products. Among several export performance indicators, there exists an even more limited number of studies providing evidence on the role of FDI and innovation in increasing countries' export quality. Motivated by these facts, the purpose of this study is to empirically investigate whether FDI and patent applications act as a channel of knowledge spillovers in improving the quality of exports in host countries ${ }^{1}$.

1 Changes in demand (supply) patterns as the importer's (exporter's) GDP rises affect export quality due to non-homothetic preferences. There exists an important body of literature focusing on the effects of foreign market GDP patterns on determining the quality of exports (see Picard and Tampieri, 2016). 
We specifically test whether FDI and patent applications increase sophistication of export baskets of host economies. Quality of exports is proxied by sophistication of export baskets as this index reflects the idea that some products need more expertise and capabilities than others so that they are more sophisticated (Hausmann et al., 2007; Hidalgo and Hausmann, 2009) $)^{2}$. Countries with higher capabilities and expertise specialize in sophisticated goods and these capabilities cannot be defined a priori, but can be inferred from the network of countries and the products they export (Hausmann et al., 2007; Hidalgo et al., 2007, Hidalgo and Hausmann, 2009; Hausmann et al., 2014). Recent literature has shown that an increase in the "sophistication" of a country's export basket is found to be a key component of economic growth (Minondo, 2010; Jarreau and Poncet, 2012).

Such an analysis contributes to the limited literature on the impact of knowledge spillovers from FDI and innovation activities on countries' export quality in many ways. With regards to the FDI-export quality literature, very few studies focus on export sophistication. Among them, $\mathrm{Xu}$ and $\mathrm{Lu}$ (2009) is one of the exceptions analysing the effect of FDI on export sophistication. However, in contrast with our study - which examines a panel of countries - they focus on China's manufacturing industries. Similar to our approach, Iwamoto and Nabeshima (2012) and Zhu and Fu (2013) investigate the impact of FDI on export sophistication of host countries utilizing a dynamic panel data model. We differ from these studies by controlling for other potential knowledge spillover channels such as innovative activities. In particular, unlike the relevant literature, our study is the first to measure the impact of FDI and patent applications within the same model. In terms of patents-export quality literature, there exist studies analysing the role of R\&D spillovers (Leon-Ledesma, 2005; Zhu and Fu, 2013; Yu and $\mathrm{Hu}, 2015$ ) and patent applications (Blind and Jungmittag, 2006; Ivus, 2010) on export quality. However, these studies either utilize R\&D as an innovation indicator (Leon-Ledesma, 2005; Zhu and $\mathrm{Fu}, 2013$; Yu and $\mathrm{Hu}, 2015$ ) or export intensity (Leon-Ledesma, 2005; Blind and Jungmittag, 2006) or technology of exports (Ivus, 2010) as an export performance indicator. To the best of our knowledge, this study is the first to analyse the impact of patent applications on export sophistication of countries. Finally, with a novel approach we contribute by analysing the role of absorptive capacity of host countries in terms of financial development, human capital and globalization level in governing this relationship.

The direction and magnitude of the impact of knowledge spillovers on exporting activity of host countries may depend on their absorptive capacity (Cohen and Levinthal,

2 There exist others measures of export quality such as higher and lower-quality exports under vertical and horizontal differentiation (for details, see Picard and Tampieri, 2016; Jaimovich and Merella, 2015) 
1990; Liang, 2017). Thus, we further investigate whether countries' education, financial development and globalization levels have a determinant role on the relationship between knowledge spillover channels and sophistication of exports. To do so, we construct a rich panel data set with 113 countries, which comprise both developed and developing countries for the period 2002-2015. To control for potential endogeneity between knowledge spillover channels and export sophistication and govern the dynamic nature of the problem, we utilize the Generalized Method of Moments (GMM) dynamic panel estimator developed by Arellano and Bond (1991). The GMM is an appropriate methodology when there are high correlations between main independent and dependent variables (Iwamoto and Nabeshima, 2012; Leitao, 2012; Zhu and Fu, 2013).

We conceptualize that the higher the absorptive capacity of a country the more it can benefit from knowledge spillovers. First, we question whether there are any systematic differences in the impact of spillovers on sophistication of exports between developed and developing countries. The impact of FDI and patent applications is expected to be smaller in developing countries with respect to developed ones due to "threshold externalities". In addition, developing countries have to reach a certain level of education, technology and infrastructure before taking advantage of foreign investments (OECD, 2001).

Next, we investigate whether the relationship between FDI, patents and sophistication differs with respect to countries' financial development level. Previous studies reveal that the influence of FDI on countries with well-developed financial markets is positively significant; otherwise, it is unclear (see, e.g., Hermes and Lensink, 2003; Alfaro et al., 2010). Financial development enhances the role of FDI and patents in spurring technological progress and sophistication of exports. Via financial development, countries' absorptive capacity increases as they reduce the costs of finding financial resources, ease access to finance (Rajan and Zingales, 1998) and promote accumulation of capital by reducing moral hazard and adverse selection. Financial development also facilitates accumulation of new ideas (Ang, 2011). Furthermore, financial development is empirically shown to be one of the determinants of export sophistication (Huang and Chen, 2014; Yu and Hu, 2015).

Besides, we examine the role of countries' educational level on the relevant relation-ships. The benefits of advanced technological knowledge can only be realized after a certain level of educational attainment (Borensztein et al., 1998). Put differently, without educated human capital, new advanced knowledge owing to FDI and patent applications cannot be used to produce sophisticated products. Furthermore, a small number of studies reveal the positive impact of education on export sophistication (Anand et al., 2012; Zhu and Fu, 2013). 
Finally, we also hypothesize that knowledge spillovers stemming from FDI or patent applications can improve quality of exports more in globalized countries than the others. With globalization, integration of societies and economies facilitates the stream of knowledge and technological diffusion across national borders (Grossman and Helpman, 2015). Thus, further knowledge accumulated due to FDI and patent applications can encourage inventing sophisticated products and improving existing products by increasing efficiency in economic activities. Also, globalization is closely related to growth of international trade in goods and services and growth of foreign direct investment (Chang et al., 2010; Leitao, 2012). At the same time, globalization can further stimulate innovation by leveraging economies of scale. The ability to benefit from prices on integrated markets can be cost-effective for innovations (Grossman and Helpman, 2015). In these respects, globalization also seems to be related to the number of patent applications, as likely is FDI.

\section{Data and Methodology}

The aim of this paper is to investigate the impact of knowledge spillovers on quality of export baskets. For this reason, the value of sophistication of exports is chosen to proxy the quality of exports. In our model, we use the sophistication index as our dependent variable. This index reflects the idea that some products need more expertise and capabilities than others so that they are more sophisticated (Hausmann et al., 2007; Hidalgo and Hausmann, 2009). Countries with higher capabilities and expertise specialize in sophisticated goods and these capabilities cannot be defined a priori, but can be inferred from the network of countries and the products they export. More formally, to define this sophistication index, Hausmann et al. (2007) first measure the sophistication level of each product with an index called PRODY. Specifically, when $m$ is the index of countries and $n$ is the index of goods, the total export of the country $m\left(X_{m}\right)$ can be written as:

$$
X_{m}=\sum_{n} x_{m n} .
$$

The productivity level related to the product $s, P R O D Y_{s}$, is represented as:

$$
\operatorname{PRODY}_{s}=\sum_{m} \frac{\left(x_{m s} / X_{m}\right)}{\sum m\left(x_{m s} / X_{m}\right)} Y_{m} .
$$

where $Y_{m}$ is the per-capita GDP of the country $m$. Here, $x_{m s} / X_{m}$ shows the value-share of goods in the country's export basket. Also, $\Sigma_{m}\left(x_{m s} / X_{m}\right)$ sums up the value share of all exporting countries. Therefore, $P R O D Y_{s}$ indicates "a weighted average per capita GDP, where the weights correspond to the Revealed Comparative Advantage (RCA) of each country in the good $s "$. 
Also, the productivity level related to the country c's export basket, EXPY, i.e., the sophistication level of exports of countries, is described by

$$
E X P Y_{c}=\sum_{n}\left(\frac{x_{c n}}{X_{c}}\right) P R O D Y_{n} .
$$

$E X P Y_{c}$ is "the weighted average of the $P R O D Y_{n}$ for that country, where the weights are simply the value shares of the products in the country's total exports" (Hausmann, 2007).

In our analysis, FDI and patent applications are the key knowledge spillover variables. In addition, to control for other factors that contribute to quality of exports, our estimation model comprises a set of conditioning variables such as GDP, savings and population. Additional control variables such as GDP deflator, regulatory quality and political stability indicators are added for robustness checks.

Besides, we investigate whether the impact of knowledge spillovers differentiates with respect to host countries' financial development, education and globalization levels. We proxy countries' financial development level with “domestic credit to private sector", education level with "enrolment in tertiary education", and globalization level with "the KOF Index of Globalization". To create different threshold levels, we use mean values of our proxies in a certain year. Using these thresholds, we create three dummy variables for financial development, education and globalization levels respectively. The relevant dummies are equal to 1 when the actual value of the variable is higher than its mean (or median) in a certain year, and 0 otherwise. In other words, these dummies take 1 if a country is more financially developed (or educated, or globalized) with respect to others and 0 otherwise.

To examine the regarding relationship, we draw a panel data set of 113 countries, which includes both developed and developing countries classified by the United Nations (UN), for the period 2002-2015. The following table presents the list of variables used in the analysis. 
Dependent Variable

\begin{tabular}{l|l|l}
\hline Variable Name & \multicolumn{1}{|c|}{ Description } & \multicolumn{1}{c}{ Source } \\
\hline Sophex & Logarithm of Export Sophistication & $\begin{array}{l}\text { World Bank: The World Integrated Trade } \\
\text { Solutions Database (WITS) }\end{array}$ \\
\hline Variable Name & \multicolumn{2}{|c}{ Knowledge Spillover Variables } \\
\hline Patent & $\begin{array}{l}\mid c \\
\text { Logcription } \\
\text { Application (per million people) }\end{array}$ & \multirow{2}{*}{$\begin{array}{l}\text { World Bank: World Development } \\
\text { Indicators }\end{array}$} \\
\hline FDI & Logarithm of the ratio of FDI to GDP &
\end{tabular}

Conditioning Variables Set

\begin{tabular}{|c|c|c|}
\hline Variable Name & Description & Source \\
\hline GDP & Logarithm of GDP Per Capita & $\begin{array}{l}\text { World Bank: The World Integrated Trade } \\
\text { Solutions Database (WITS) }\end{array}$ \\
\hline Law & Rule of Law Index & \multirow{3}{*}{$\begin{array}{l}\text { World Bank: The Worldwide Governance } \\
\text { Indicators }\end{array}$} \\
\hline Regulatory & Regulatory Quality Index & \\
\hline Stability & Political Stability Index & \\
\hline Saving & $\begin{array}{l}\text { Logarithm of Ratio of Gross Saving } \\
\text { to GDP }\end{array}$ & \multirow{2}{*}{$\begin{array}{l}\text { World Bank: World Development } \\
\text { Indicators }\end{array}$} \\
\hline Population & Logarithm of Population & \\
\hline Credit & $\begin{array}{l}\text { Domestic Credit to Private Sector (\% } \\
\text { of GDP) }\end{array}$ & \multirow{3}{*}{$\begin{array}{l}\text { World Bank: Global Financial } \\
\text { Development Database (GFDD) }\end{array}$} \\
\hline Liquid & Liquid liabilities to GDP (\%) & \\
\hline Private & $\begin{array}{l}\text { Private credit by deposit money } \\
\text { banks to GDP (\%) }\end{array}$ & \\
\hline Tertiary & $\begin{array}{l}\text { Enrolment in tertiary education } \\
\text { (number) (per people) }\end{array}$ & $\begin{array}{l}\text { UIS (UNESCO Institute for Statistics): } \\
\text { World Education Indicators }\end{array}$ \\
\hline Secondary & $\begin{array}{l}\text { Secondary School Gross Enrolment } \\
\text { Ratio \% of Relevant Age Group }\end{array}$ & $\begin{array}{l}\text { UIS (UNESCO Institute for Statistics): } \\
\text { World Education Indicators }\end{array}$ \\
\hline Globalization & Globalization Index & KOF Swiss Economic Institute \\
\hline EconGlob & Economic Globalization Index & KOF Swiss Economic Institute \\
\hline
\end{tabular}

Source: Prepared by authors. 
As the relationship between knowledge spillovers and exports is dynamic in nature, we apply a dynamic specification ${ }^{3}$. Accordingly, the estimation equation involving the lag of the dependent variable is expressed as:

$$
\begin{aligned}
& Y_{i t}=\varphi Y_{i, t-1}+\beta X_{i t}^{\prime}+U_{i t}, \\
& U_{i t}=\mu_{i}+u_{i t} .
\end{aligned}
$$

where $Y_{i t}$ is the sophistication of export in the country $i$ and the year $t, X_{i t}^{\prime}$ is a vector of knowledge spillover indicators and conditioning variables and $U_{i t}$ is an i.i.d. error term. Equation (1) represents a standard dynamic panel data specification. In such a specification, the presence of the lagged values of the dependent variable among the explanatory variables requires careful selection of the estimation methodology. Since the dependent variable is associated with the error term " $U_{i t}$ " containing individual effects " $\mu_{i}$ " and $Y_{i, t-1}$ is also associated with error terms, the standard predictors as in ordinary least-squares (OLS) methodology give inconsistent and biased results. Also, country-specific effects cause the OLS estimator to be biased. In this case, the assumption of uncorrelated error terms and explanatory variables becomes invalid. A fixed-effects estimator which removes country-specific effects cannot be used as an alternative since the inclusion of a lagged dependent variable will still create a bias. In order to prevent this, Generalized Method of Moments (GMM) estimators are often used (Bond, 2002). We use Arellano and Bond's (1991) difference GMM estimator. The Arellano-Bond GMM estimator is designed for panels with short time series, models with dynamic processes and non-exogenous state of variables (Roodman, 2006). Under these conditions, the GMM estimator is the most appropriate method for the analysis in question.

The consistency of the GMM estimator depends on two basic tests. The first is the Arellano-Bond test (AB test), which tests for serial correlation in first-differenced errors. GMM estimator does not allow any autocorrelation in the idiosyncratic errors. The second is the Sargan (1958) J-test, which tests for over-identifying restrictions.

\section{Estimation Results}

To begin with, the link between export sophistication and knowledge spillover variables in terms of patents and FDI is investigated in Equation (4) as follows:

$$
\text { Sophex }_{i, t}=\alpha+\text { Sophex }_{i, t-1}+\beta_{1} \text { Patent }_{i, t-1}+\beta_{2} F D I_{i, t-1}+\beta_{3} F D I_{i, t-2}+\delta \text { Controls } \varepsilon_{i t},
$$

where the subscript $i$ denotes countries and $t$ represents years. As mentioned in the data section, the dependent variable measures the logarithm of the export sophistication index

3 Besides, "the inclusion of the lagged dependent variable is merited by the fact that its introduction can also serve as a proxy for the unobserved serially correlated state variables" (Kostevc, 2005). 
of the country $i$ at the time $t$. To avoid endogeneity and to observe the impact of time delays in creation of spillovers, we use lags of knowledge spillover variables. Knowledge is accumulated in the course of time; hence, spillover effects on exports may take time. In the literature, there is no consensus on how to decide the optimal lag selection in the context of knowledge spillovers. Although there is little theoretical guidance relating to the appropriate time period for absorption of new ideas, two-year lagged FDI (Zhang, cited in Zhang and Qingsong 2019) or five-year lagged FDI (Kemeny, 2010; Iwamoto and Nabeshima, 2012) are generally used. However, a fairly new study shows that the appropriate time lag of FDI spillover changes (see Zhang and Qingsong, 2019). Moreover, in terms of patent applications, a one-year lag is often used (Chang et al., 2010). In order to estimate a valid model, we use the first and second lags of the FDI indicator and the first lag of the patent variable, respectively.

To measure the effects of FDI and patent applications on sophistication level of countries' exports, we first run the regressions on the whole sample. In Table 2, the first column indicates the results where a patent is used as the only knowledge spillover variable, while Column 2 shows the relevant results for FDI. Column 3 presents the results where both patent applications and FDI are used together as knowledge spillover variables. As seen from the table, patent applications are found to have a positively significant effect on export sophistication and this result does not change even after controlling for FDI. However, FDI does not seem to have any significant effect on export sophistication. The negative competition effects of FDI may balance out the productivity and knowledge benefits when countries are taken as a whole. To summarize, our results suggest that patent applications which may create knowledge spillovers positively impact on the export sophistication of countries. However, FDI may not bring about any improvements in export sophistication.

Now, we attest whether the impacts of FDI and patent applications vary with respect to countries' development level. Particularly, we question whether there are any systematic differences in the impact of FDI and patents on sophistication of exports between developed and developing countries. Since we are interested in studying cross-country variations in the efficiency of knowledge spillovers, we divide our sample into sub-samples of developed and developing countries. In order to investigate this question, the benchmarking regression is run separately for the two sub-samples. The results of these estimations are reported in Table 2, where Column 4 indicates the results for developed countries, while Column 5 shows the estimation outcomes for developing countries. The results indicate that patent applications positively impact on export sophistication in both developed and developing countries. Unlike patents, the impact of FDI varies among countries. The coefficient of FDI is positively significant for developed countries, whereas it is negatively significant for developing ones. These results suggest that FDI serves as a channel for knowledge 
spillovers to benefit the sophistication level of exports only for developed countries, as mentioned in OECD (2001). This paradoxical result can be attributed to the worse investment climate conditions and government policies in developing countries.

Table 2: GMM estimates on sophistication of exports for all, developed and developing countries

\begin{tabular}{|c|c|c|c|c|c|}
\hline & (1) & (2) & (3) & (4) & (5) \\
\hline & All & All & All & Developed & Developing \\
\hline L.Sophex & $\begin{array}{c}-0.1230^{* *} \\
(0.0565)\end{array}$ & $\begin{array}{l}-0.1610 \\
(0.2010)\end{array}$ & $\begin{array}{l}-0.0928 \\
(0.0698)\end{array}$ & $\begin{array}{l}0.4470^{* * *} \\
(0.1190)\end{array}$ & $\begin{array}{c}-0.0224 \\
(0.1180)\end{array}$ \\
\hline L.GDP & $\begin{array}{l}-0.0375 \\
(0.0267)\end{array}$ & $\begin{array}{c}0.0750 \\
(0.0486)\end{array}$ & $\begin{array}{l}-0.0370 \\
(0.0269)\end{array}$ & $\begin{array}{c}0.0140 \\
(0.0139)\end{array}$ & $\begin{array}{l}-0.0665 \\
(0.0650)\end{array}$ \\
\hline L.Patent & $\begin{array}{l}\mathbf{0 . 0 2 7 0}^{* *} \\
(0.0119)\end{array}$ & - & $\begin{array}{l}\mathbf{0 . 0 2 9 9} * * \\
(0.0118)\end{array}$ & $\begin{array}{l}\mathbf{0 . 0 0 9 1 *} \\
(0.0051)\end{array}$ & $\begin{array}{l}\mathbf{0 . 0 2 8 7}^{*} \\
(0.0147)\end{array}$ \\
\hline L.FDI & - & $\begin{array}{l}0.00054 \\
(0.0035)\end{array}$ & $\begin{array}{l}-0.0024 \\
(0.0038)\end{array}$ & $\begin{array}{c}0.0014 \\
(0.0009)\end{array}$ & $\begin{array}{l}-0.0118 \\
(0.0098)\end{array}$ \\
\hline L2.FDI & - & $\begin{array}{c}-0.0049 \\
(0.0039)\end{array}$ & $\begin{array}{c}-0.0043 \\
(0.0036)\end{array}$ & $\begin{array}{l}\mathbf{0 . 0 0 3 2} * * \\
(0.0013)\end{array}$ & $\begin{array}{c}-\mathbf{0 . 0 2 1 5} * \\
(0.0118)\end{array}$ \\
\hline Law & $\begin{array}{c}0.0525^{*} \\
(0.0307)\end{array}$ & $\begin{array}{c}0.0327 \\
(0.0337)\end{array}$ & $\begin{array}{c}0.0387 \\
(0.0438)\end{array}$ & $\begin{array}{c}0.0121 \\
(0.0234)\end{array}$ & $\begin{array}{c}0.0354 \\
(0.0533)\end{array}$ \\
\hline Population & $\begin{array}{c}0.1960 \\
(0.1520)\end{array}$ & $\begin{array}{l}0.0590 \\
(0.107)\end{array}$ & $\begin{array}{c}0.1720 \\
(0.1550)\end{array}$ & $\begin{array}{c}-0.2150^{* *} \\
(0.1020)\end{array}$ & $\begin{array}{l}0.3420^{*} \\
(0.1900)\end{array}$ \\
\hline Saving & $\begin{array}{c}0.0204 \\
(0.0136)\end{array}$ & $\begin{array}{l}0.0318^{*} \\
(0.0189)\end{array}$ & $\begin{array}{c}0.0183 \\
(0.0139)\end{array}$ & $\begin{array}{c}0.0155^{* *} \\
(0.0070)\end{array}$ & $\begin{array}{c}0.0285 \\
(0.0245)\end{array}$ \\
\hline Constant & $\begin{array}{l}7.8810^{* * *} \\
(2.8480)\end{array}$ & $\begin{array}{l}9.4660^{* * *} \\
(2.9480)\end{array}$ & $\begin{array}{l}7.9840^{* * *} \\
(2.9820)\end{array}$ & $\begin{array}{l}8.7640^{* * *} \\
(1.3890)\end{array}$ & $\begin{array}{c}4.4860 \\
(3.3860)\end{array}$ \\
\hline Observations & 828 & 905 & 679 & 276 & 326 \\
\hline Number of id & 88 & 105 & 86 & 32 & 44 \\
\hline
\end{tabular}

Note: Robust standard errors are in brackets. ${ }^{* * *},{ }^{* *}$ and ${ }^{*}$ indicate statistical significance at the $1 \%, 5 \%$ and $10 \%$ level, respectively.

Source: Authors' calculations. Motivated by the idea that countries' absorptive capacities for new knowledge affect the impact of knowledge spillovers (Cohen and Levinthal, 1990; Liang, 2017), we investigate whether the relationship between FDI, patents and sophistication of exports differs with respect to countries' financial development, education and globalization levels. To do so, we create three different threshold levels with respect to the average of each indicator of absorptive capacity and create sub-samples of countries accordingly. We consider countries above these thresholds to be more developed than those below. Then we re-estimate the benchmarking regressions for the groups of more developed and less developed countries in terms of finance, education and globalization. The results are presented in Table 3. 
First, to proxy a country's financial development level, we utilize "credit to private sector as a percentage of GDP" indicator and divide our sample into two sub-groups: "more financially developed" versus "less financially developed" countries. In Table 3, the first two columns represent the output of the relevant estimations. The coefficient of patents continues to be positively significant for all countries, yet the signs of the coefficient of FDI vary according to the financial development level. In more financially developed countries, FDI is found to contribute to export sophistication, whereas in less financially developed countries it does not appear to contribute at all. The results may indicate that positive spillovers from FDI arise when the country has developed financial markets. We also conduct two alternative models to control for the robustness of the estimations where we utilize two different financial development indicators: "liquid liabilities" and "private credit by deposit money banks". All of these models yield similar outcomes. Table 4 presents the estimated results. The impact of FDI and patents on export sophistication is robust across other financial development indicators.

Next, following Borensztein et al. (1998), we investigate the role of education on the association between knowledge spillover channels and export sophistication. We divide our sample into more educated and less-educated countries using the number of tertiary school enrolment as an indicator of human capital level. The countries above the average level of tertiary education for a given year are considered to be more educated, while the countries below are considered to be less educated. In Table 3, the fourth and fifth columns present the estimated results for countries with higher and lower education levels, respectively. Contrary to the previous results, the coefficients of patents are positively significant only for more educated countries. In other words, in countries with lower educational attainment, an increase in the number of patents may not bring any improvements in sophistication level of exports. This result may stem from the following observation that the number of patents shows that the potential inventions in a country and new inventions lead to the emergence of new knowledge. However, due to the low levels of human capital, new knowledge may not be used efficiently to promote the quality of exports in terms of sophistication. Similarly, the impact of FDI on export sophistication depends on countries' education level. It is obviously seen that the coefficient of FDI is positive and statistically significant only for more educated countries. As mentioned before, in the absence of educated human capital, new advanced knowledge sourced by FDI cannot be used to produce sophisticated products and export them. To control for the robustness of the estimation results, we conduct an alternative model using a different education level indicator: "secondary school gross enrolment ratio". Patent applications are positive and statistically significant for both groups. However, the coefficients of FDI become insignificant in some of the estimations. This may stem from the observation that secondary school enrolment is more common than tertiary school enrolment. 
Table 3: GMM estimates on sophistication of exports according to absorptive capacity of countries in terms of countries' financial development, education and globalization level

\begin{tabular}{|c|c|c|c|c|c|c|}
\hline & (1) & (2) & (3) & (4) & (5) & (6) \\
\hline & $\begin{array}{c}\text { More } \\
\text { Financially } \\
\text { Developed }\end{array}$ & $\begin{array}{l}\text { Less } \\
\text { Financially } \\
\text { Developed }\end{array}$ & $\begin{array}{c}\text { More } \\
\text { Educated }\end{array}$ & $\begin{array}{c}\text { Less } \\
\text { Educated }\end{array}$ & $\begin{array}{c}\text { More } \\
\text { Globalized }\end{array}$ & $\begin{array}{c}\text { Less } \\
\text { Globalized }\end{array}$ \\
\hline L.Sophex & $\begin{array}{l}0.3250 * \\
(0.1680)\end{array}$ & $\begin{array}{l}-0.0803 \\
(0.1200)\end{array}$ & $\begin{array}{c}0.4340^{* * *} \\
(0.0794)\end{array}$ & $\begin{array}{l}-0.1190 \\
(0.0886)\end{array}$ & $\begin{array}{c}0.2800^{* * *} \\
(0.1040)\end{array}$ & $\begin{array}{l}-0.0569 \\
(0.1250)\end{array}$ \\
\hline L.GDP & $\begin{array}{l}-0.0141 \\
(0.0219)\end{array}$ & $\begin{array}{l}-0.0427 \\
(0.0352)\end{array}$ & $\begin{array}{l}-0.0172 \\
(0.0143)\end{array}$ & $\begin{array}{l}-0.1100 \\
(0.0673)\end{array}$ & $\begin{array}{l}-0.0180 \\
(0.0246)\end{array}$ & $\begin{array}{l}-0.0639 \\
(0.0577)\end{array}$ \\
\hline L.Patent & $\begin{array}{l}\mathbf{0 . 0 2 5 2} \mathbf{2}^{* *} \\
(0.0105)\end{array}$ & $\begin{array}{l}\mathbf{0 . 0 2 9 5} * * * \\
(0.0102)\end{array}$ & $\begin{array}{l}\mathbf{0 . 0 1 2 0} * * \\
(0.0050)\end{array}$ & $\begin{array}{l}\mathbf{0 . 0 2 5 3} \\
(0.0169)\end{array}$ & $\begin{array}{l}\mathbf{0 . 0 1 2 1 * *} \\
(0.0062)\end{array}$ & $\begin{array}{l}\mathbf{0 . 0 2 7 7 * *} \\
(0.0131)\end{array}$ \\
\hline L.FDI & $\begin{array}{c}0.0014 \\
(0.0011)\end{array}$ & $\begin{array}{l}-0.0096 \\
(0.0092)\end{array}$ & $\begin{array}{l}0.0016^{* *} \\
(0.0008)\end{array}$ & $\begin{array}{l}-0.0049 \\
(0.0087)\end{array}$ & $\begin{array}{c}0.0014 \\
(0.0010)\end{array}$ & $\begin{array}{l}-0.0156 \\
(0.0123)\end{array}$ \\
\hline L2.FDI & $\begin{array}{l}\mathbf{0 . 0 0 3 2} 2^{* *} \\
(0.0016)\end{array}$ & $\begin{array}{c}-\mathbf{0 . 0 1 8 8 * *} \\
(0.0095)\end{array}$ & $\begin{array}{l}\mathbf{0 . 0 0 3 8} \mathbf{8}^{* * *} \\
(0.0014)\end{array}$ & $\begin{array}{c}-0.0214^{*} \\
(0.0126)\end{array}$ & $\begin{array}{l}\mathbf{0 . 0 0 3 0} \text { ** } \\
(0.0015)\end{array}$ & $\begin{array}{c}-\mathbf{0 . 0 3 4 4} 4^{* *} \\
(0.0134)\end{array}$ \\
\hline Law & $\begin{array}{l}0.0452^{* *} \\
(0.0217)\end{array}$ & $\begin{array}{c}0.0369 \\
(0.0709)\end{array}$ & $\begin{array}{c}0.0312 \\
(0.0195)\end{array}$ & $\begin{array}{c}0.0186 \\
(0.1280)\end{array}$ & $\begin{array}{c}0.0341 \\
(0.0235)\end{array}$ & $\begin{array}{c}0.0513 \\
(0.0652)\end{array}$ \\
\hline Population & $\begin{array}{l}0.1510^{*} \\
(0.0777)\end{array}$ & $\begin{array}{c}0.1660 \\
(0.2980)\end{array}$ & $\begin{array}{l}-0.0489 \\
(0.0800)\end{array}$ & $\begin{array}{c}0.3740 \\
(0.4630)\end{array}$ & $\begin{array}{c}0.0929 \\
(0.0957)\end{array}$ & $\begin{array}{c}0.4030 \\
(0.2680)\end{array}$ \\
\hline Saving & $\begin{array}{l}0.0164^{* *} \\
(0.0072)\end{array}$ & $\begin{array}{c}0.0295 \\
(0.0282)\end{array}$ & $\begin{array}{l}0.0110^{* * *} \\
(0.0039)\end{array}$ & $\begin{array}{c}0.0482 \\
(0.0363)\end{array}$ & $\begin{array}{l}0.0146 * * \\
(0.0065)\end{array}$ & $\begin{array}{c}0.0329 \\
(0.0277)\end{array}$ \\
\hline Constant & $\begin{array}{l}4.0530^{* *} \\
(1.8010)\end{array}$ & $\begin{array}{c}7.9150 \\
(5.8380)\end{array}$ & $\begin{array}{l}6.4440^{* * *} \\
(1.3870)\end{array}$ & $\begin{array}{c}5.0600 \\
(8.6200)\end{array}$ & $\begin{array}{l}5.6250 * * * \\
(1.0370)\end{array}$ & $\begin{array}{c}3.7000 \\
(5.1460)\end{array}$ \\
\hline Observations & 313 & 357 & 332 & 189 & 384 & 262 \\
\hline Number of id & 42 & 53 & 50 & 35 & 50 & 41 \\
\hline
\end{tabular}

Note: Robust standard errors are in brackets. ${ }^{* * *},{ }^{* *}$ and ${ }^{*}$ indicate statistical significance at the $1 \%, 5 \%$ and $10 \%$ level, respectively.

Source: Authors' calculations. 
Table 4: GMM estimates on sophistication for sub-samples by financial development level with alternative indicators

\begin{tabular}{|c|c|c|c|c|c|c|}
\hline & (1) & (2) & (3) & (4) & (5) & (6) \\
\hline \multirow[t]{2}{*}{$\begin{array}{l}\text { Alternative } \\
\text { Financial } \\
\text { development } \\
\text { indicators }\end{array}$} & \multicolumn{2}{|c|}{$\begin{array}{l}\text { Liquid liabilities } \\
\text { to GDP (\%) }\end{array}$} & \multicolumn{2}{|c|}{$\begin{array}{c}\text { Private credit by } \\
\text { deposit money banks } \\
\text { to GDP (\%) }\end{array}$} & \multicolumn{2}{|c|}{$\begin{array}{l}\text { Domestic Credit } \\
\text { to Private Sector } \\
\text { (\% of GDP) }\end{array}$} \\
\hline & $\begin{array}{l}\text { More } \\
\text { Financially } \\
\text { Developed }\end{array}$ & $\begin{array}{l}\text { Less } \\
\text { Financially } \\
\text { Developed }\end{array}$ & $\begin{array}{l}\text { More } \\
\text { Financially } \\
\text { Developed }\end{array}$ & $\begin{array}{l}\text { Less } \\
\text { Financially } \\
\text { Developed }\end{array}$ & $\begin{array}{l}\text { More } \\
\text { Financially } \\
\text { Developed }\end{array}$ & $\begin{array}{l}\text { Less } \\
\text { Financially } \\
\text { Developed }\end{array}$ \\
\hline L.Sophex & $\begin{array}{l}0.315^{*} \\
(0.169)\end{array}$ & $\begin{array}{c}-0.0662 \\
(0.104)\end{array}$ & $\begin{array}{l}0.325^{*} \\
(0.168)\end{array}$ & $\begin{array}{c}-0.0803 \\
(0.120)\end{array}$ & $\begin{array}{l}0.209 \\
(0.170)\end{array}$ & $\begin{array}{c}-0.0795 \\
(0.122)\end{array}$ \\
\hline L.GDP & $\begin{array}{l}0.00110 \\
(0.0286)\end{array}$ & $\begin{array}{l}-0.0308 \\
(0.0311)\end{array}$ & $\begin{array}{l}-0.0141 \\
(0.0219)\end{array}$ & $\begin{array}{l}-0.0427 \\
(0.0352)\end{array}$ & $\begin{array}{l}-0.0117 \\
(0.0224)\end{array}$ & $\begin{array}{l}-0.0609 \\
(0.0398)\end{array}$ \\
\hline L.Patent & $\begin{array}{l}\mathbf{0 . 0 2 4 7 * *} \\
(0.0123)\end{array}$ & $\begin{array}{l}\mathbf{0 . 0 2 5 4} \mathbf{H}^{* * *} \\
(0.00916)\end{array}$ & $\begin{array}{l}\mathbf{0 . 0 2 5 2} \mathbf{2}^{* *} \\
(0.0105)\end{array}$ & $\begin{array}{l}\mathbf{0 . 0 2 9 5} * * * \\
(0.0102)\end{array}$ & $\begin{array}{c}\mathbf{0 . 0 3 2 0} * * * \\
(0.0109)\end{array}$ & $\begin{array}{l}\mathbf{0 . 0 2 8 7} * * * \\
(0.0104)\end{array}$ \\
\hline L.FDI & $\begin{array}{c}0.00149 \\
(0.00108)\end{array}$ & $\begin{array}{c}-0.00844 \\
(0.00714)\end{array}$ & $\begin{array}{c}0.00143 \\
(0.00112)\end{array}$ & $\begin{array}{l}-0.00964 \\
(0.00924)\end{array}$ & $\begin{array}{l}0.000760 \\
(0.00103)\end{array}$ & $\begin{array}{l}-0.00962 \\
(0.00967)\end{array}$ \\
\hline L2.FDI & $\begin{array}{l}\mathbf{0 . 0 0 3 5 6 * *} \\
(0.00163)\end{array}$ & $\begin{array}{l}-\mathbf{0 . 0 1 6 7 * *} \\
(0.00825)\end{array}$ & $\begin{array}{l}\mathbf{0 . 0 0 3 2 1 * *} \\
(0.00157)\end{array}$ & $\begin{array}{c}-\mathbf{0 . 0 1 8 8 * *} \\
(0.00945)\end{array}$ & $\begin{array}{l}\mathbf{0 . 0 0 2 8 3} * \\
(0.00158)\end{array}$ & $\begin{array}{l}-\mathbf{0 . 0 1 9 0 *} \\
(0.00979)\end{array}$ \\
\hline Law & $\begin{array}{l}0.0204 \\
(0.0199)\end{array}$ & $\begin{array}{c}0.0474 \\
(0.0583)\end{array}$ & $\begin{array}{l}0.0452^{* *} \\
(0.0217)\end{array}$ & $\begin{array}{c}0.0369 \\
(0.0709)\end{array}$ & $\begin{array}{l}0.0470^{* *} \\
(0.0229)\end{array}$ & $\begin{array}{c}0.0391 \\
(0.0681)\end{array}$ \\
\hline Population & $\begin{array}{c}0.172^{*} \\
(0.0957)\end{array}$ & $\begin{array}{c}0.141 \\
(0.252)\end{array}$ & $\begin{array}{c}0.151^{*} \\
(0.0777)\end{array}$ & $\begin{array}{c}0.166 \\
(0.298)\end{array}$ & $\begin{array}{c}0.147^{*} \\
(0.0891)\end{array}$ & $\begin{array}{c}0.236 \\
(0.283)\end{array}$ \\
\hline Saving & $\begin{array}{l}0.0238 * * * \\
(0.00449)\end{array}$ & $\begin{array}{l}0.0220 \\
(0.0214)\end{array}$ & $\begin{array}{c}0.0164^{* *} \\
(0.00719)\end{array}$ & $\begin{array}{c}0.0295 \\
(0.0282)\end{array}$ & $\begin{array}{c}0.0158^{* *} \\
(0.00619)\end{array}$ & $\begin{array}{c}0.0301 \\
(0.0285)\end{array}$ \\
\hline Constant & $\begin{array}{l}3.627^{* *} \\
(1.801)\end{array}$ & $\begin{array}{l}8.159 * \\
(4.876)\end{array}$ & $\begin{array}{l}4.053^{* *} \\
(1.801)\end{array}$ & $\begin{array}{c}7.915 \\
(5.838)\end{array}$ & $\begin{array}{l}5.235^{* * *} \\
(1.938)\end{array}$ & $\begin{array}{c}6.886 \\
(5.598)\end{array}$ \\
\hline Observations & 313 & 357 & 336 & 332 & 346 & 333 \\
\hline Number of id & 42 & 53 & 47 & 53 & 47 & 52 \\
\hline
\end{tabular}

Note: Robust standard errors are in brackets. ${ }^{* * *},{ }^{* *}$ and ${ }^{*}$ indicate statistical significance at the $1 \%$, $5 \%$ and $10 \%$ level, respectively.

Source: Authors' calculations. 
We further investigate the impact of countries' globalization level on the relationship between knowledge spillover variables and export sophistication. For countries' globalization level, we use the KOF Index of Globalization, which reflects countries' globalization in terms of economic, social and political globalization (Potrafke, 2015). In order to measure the effect of globalization, we divide countries into two groups. The countries above the mean of the globalization level of a given year are considered to be more globalized, whereas the countries below the mean are considered to be less globalized. In Table 3, the last two columns show the results according to countries' globalization level. The estimation results indicate that the impact of patents continues to be positively significant. Note that the coefficient of the patents variable in the less globalized countries is found to be larger than in the globalized economies. This result can be attributed to the fact that innovations are one of the main determinants of sophistication in less globalized countries. Moreover, the findings show that globalization level is a key factor for the impact of FDI in host countries. In the more globalized countries, FDI has a positively significant impact on the level of sophistication of exports; however, in the less globalized countries this impact turns negative. In line with the studies of Chang et al. (2010) and Leitao (2012), our results reveal that globalization is closely related to trade and FDI. Besides, utilizing the "economic globalization index" as a different globalization level indicator, we estimate an alternative model controlling for the robustness of the estimated results. The results are found to be robust across different indicators of globalization level (see Table 5, Columns 5, 6, 7 and 8). 
Table 5: GMM estimates on sophistication of exports for sub-samples by countries' education and globalization levelwith alternative indicators

\begin{tabular}{|c|c|c|c|c|c|c|c|c|}
\hline \multirow[t]{3}{*}{$\begin{array}{l}\text { Alternative } \\
\text { indicators } \\
\text { for education } \\
\text { and globali- } \\
\text { zation }\end{array}$} & \multicolumn{2}{|c|}{$\begin{array}{l}\text { Enrolment in tertiary } \\
\text { education (number) } \\
\text { (per population) }\end{array}$} & \multicolumn{2}{|c|}{$\begin{array}{c}\text { Secondary School } \\
\text { Gross Enrolment } \\
\text { Ratio \% of Relevant } \\
\text { Age Group }\end{array}$} & \multicolumn{2}{|c|}{$\begin{array}{c}\text { Globalization } \\
\text { Index }\end{array}$} & \multicolumn{2}{|c|}{$\begin{array}{l}\text { Economic } \\
\text { Globalization } \\
\text { Index }\end{array}$} \\
\hline & (1) & (2) & (3) & (4) & (5) & (6) & (7) & (8) \\
\hline & $\begin{array}{c}\text { More } \\
\text { Educated }\end{array}$ & $\begin{array}{c}\text { Less } \\
\text { Educated }\end{array}$ & $\begin{array}{c}\text { More } \\
\text { Educated }\end{array}$ & $\begin{array}{l}\text { Less } \\
\text { Educated }\end{array}$ & $\begin{array}{c}\text { More } \\
\text { Globalized }\end{array}$ & $\begin{array}{c}\text { Less } \\
\text { Globalized }\end{array}$ & $\begin{array}{c}\text { More } \\
\text { Globalized }\end{array}$ & $\begin{array}{c}\text { Less } \\
\text { Globalized }\end{array}$ \\
\hline L.Sophex & $\begin{array}{l}0.434^{* * *} \\
(0.0794)\end{array}$ & $\begin{array}{l}-0.119 \\
(0.0886)\end{array}$ & $\begin{array}{l}0.254^{*} \\
(0.130)\end{array}$ & $\begin{array}{l}-0.152 \\
(0.162)\end{array}$ & $\begin{array}{l}0.280^{* * *} \\
(0.104)\end{array}$ & $\begin{array}{r}-0.0569 \\
(0.125)\end{array}$ & $\begin{array}{l}0.172 \\
(0.106)\end{array}$ & $\begin{array}{c}-0.0176 \\
(0.135)\end{array}$ \\
\hline L.GDP & $\begin{array}{l}-0.0172 \\
(0.0143)\end{array}$ & $\begin{array}{c}-0.110 \\
(0.0673)\end{array}$ & $\begin{array}{l}-0.0314 \\
(0.0203)\end{array}$ & $\begin{array}{l}0.0557 \\
(0.115)\end{array}$ & $\begin{array}{l}-0.0180 \\
(0.0246)\end{array}$ & $\begin{array}{l}-0.0639 \\
(0.0577)\end{array}$ & $\begin{array}{l}-0.0159 \\
(0.0215)\end{array}$ & $\begin{array}{l}-0.0651 \\
(0.0614)\end{array}$ \\
\hline L.Patent & $\begin{array}{l}\mathbf{0 . 0 1 2 0 * *} \\
(0.00496)\end{array}$ & $\begin{array}{l}0.0253 \\
(0.0169)\end{array}$ & $\begin{array}{l}\mathbf{0 . 0 1 5 6 * * *} \\
(0.00506)\end{array}$ & $\begin{array}{l}\mathbf{0 . 0 4 1 0} * \\
(0.0235)\end{array}$ & $\begin{array}{l}\mathbf{0 . 0 1 2 1 * *} \\
(0.00617)\end{array}$ & $\begin{array}{l}\mathbf{0 . 0 2 7 7 * *} \\
(0.0131)\end{array}$ & $\begin{array}{l}\mathbf{0 . 0 1 8 0 * *} \\
(0.00807)\end{array}$ & $\begin{array}{l}\mathbf{0 . 0 2 5 1 *} \\
(0.0146)\end{array}$ \\
\hline L.FDI & $\begin{array}{l}0.00163^{* *} \\
(0.000825)\end{array}$ & $\begin{array}{l}-0.00493 \\
(0.00867)\end{array}$ & $\begin{array}{l}0.000472 \\
(0.000991)\end{array}$ & $\begin{array}{l}-0.00793 \\
(0.0109)\end{array}$ & $\begin{array}{l}0.00142 \\
(0.00101)\end{array}$ & $\begin{array}{l}-0.0156 \\
(0.0123)\end{array}$ & $\begin{array}{l}0.000671 \\
(0.00102)\end{array}$ & $\begin{array}{l}-0.0112 \\
(0.0109)\end{array}$ \\
\hline L2.FDI & $\begin{array}{c}\mathbf{0 . 0 0 3 8 0 * * *} \\
(0.00137)\end{array}$ & $\begin{array}{c}-0.0214 * \\
(0.0126)\end{array}$ & $\begin{array}{l}\mathbf{0 . 0 0 2 8 7 ^ { * }} \\
(0.00151)\end{array}$ & $\begin{array}{l}-0.0186 \\
(0.0125)\end{array}$ & $\begin{array}{c}\mathbf{0 . 0 0 3 0 0 * *} \\
(0.00146)\end{array}$ & $\begin{array}{c}-\mathbf{0 . 0 3 4 4 * *} \\
(0.0134)\end{array}$ & $\begin{array}{l}\mathbf{0 . 0 0 2 9 1 *} \\
(0.00155)\end{array}$ & $\begin{array}{c}-0.0297^{* *} \\
(0.0124)\end{array}$ \\
\hline Law & $\begin{array}{c}0.0312 \\
(0.0195)\end{array}$ & $\begin{array}{l}0.0186 \\
(0.128)\end{array}$ & $\begin{array}{l}0.0377^{*} \\
(0.0221)\end{array}$ & $\begin{array}{c}0.0217 \\
(0.0887)\end{array}$ & $\begin{array}{c}0.0341 \\
(0.0235)\end{array}$ & $\begin{array}{c}0.0513 \\
(0.0652)\end{array}$ & $\begin{array}{l}0.00857 \\
(0.0270)\end{array}$ & $\begin{array}{c}0.0367 \\
(0.0671)\end{array}$ \\
\hline Population & $\begin{array}{l}-0.0489 \\
(0.0800)\end{array}$ & $\begin{array}{c}0.374 \\
(0.463)\end{array}$ & $\begin{array}{c}-0.0110 \\
(0.122)\end{array}$ & $\begin{array}{l}-0.832 \\
(0.582)\end{array}$ & $\begin{array}{c}0.0929 \\
(0.0957)\end{array}$ & $\begin{array}{c}0.403 \\
(0.268)\end{array}$ & $\begin{array}{l}0.0900 \\
(0.109)\end{array}$ & $\begin{array}{c}0.307 \\
(0.283)\end{array}$ \\
\hline Saving & $\begin{array}{l}0.0110 * * * \\
(0.00387)\end{array}$ & $\begin{array}{l}0.0482 \\
(0.0363)\end{array}$ & $\begin{array}{c}0.00564 \\
(0.00417)\end{array}$ & $\begin{array}{c}0.0686 \\
(0.0530)\end{array}$ & $\begin{array}{c}0.0146^{* *} \\
(0.00650)\end{array}$ & $\begin{array}{c}0.0329 \\
(0.0277)\end{array}$ & $\begin{array}{c}0.0115^{*} \\
(0.00626)\end{array}$ & $\begin{array}{c}0.0396 \\
(0.0321)\end{array}$ \\
\hline Constant & $\begin{array}{l}6.444^{* * *} \\
(1.387)\end{array}$ & $\begin{array}{c}5.060 \\
(8.620)\end{array}$ & $\begin{array}{l}7.731^{* * *} \\
(2.025)\end{array}$ & $\begin{array}{l}25.17^{* *} \\
(11.61)\end{array}$ & $\begin{array}{l}5.625^{* * *} \\
(1.037)\end{array}$ & $\begin{array}{c}3.700 \\
(5.146)\end{array}$ & $\begin{array}{l}6.746^{* * *} \\
(1.663)\end{array}$ & $\begin{array}{c}4.861 \\
(5.766)\end{array}$ \\
\hline Observations & 332 & 189 & 427 & 137 & 384 & 262 & 373 & 273 \\
\hline Number of id & 50 & 35 & 58 & 29 & 50 & 41 & 52 & 43 \\
\hline
\end{tabular}

Note: Robust standard errors are in brackets. ${ }^{* * *},{ }^{* *}$ and ${ }^{*}$ indicate statistical significance at the $1 \%, 5 \%$ and $10 \%$ level, respectively.

Source: Authors' calculations. 
As a robustness check, we re-run all the regressions by adding additional control variables such as GDP deflator, regulatory quality and political stability indicators. The estimated results from Tables 6-10 in the Appendix confirm the robustness of our initial results. Moreover, to further examine the robustness of the estimations according to different threshold levels, we repeated the same exercises with new threshold levels determined by median values. These results are also robust to the new threshold levels determined by the median values of financial development, educational development and globalization level in a certain year. The results from the estimations are presented in Tables 1112 and 13 in the Appendix.

Finally, we would like to note that in all of our regressions, patents seem to have greater and more significant effect than FDI. This may indicate that intra-national spillovers seem to be more important than international spillovers.

\section{Conclusion}

This paper aims to explore the impact of knowledge spillovers due to FDI and patent applications on countries' quality of exports. Following the seminal works of Hausmann et al. (2007) and Lall et al. (2006), we proxy quality of exports using the export sophistication index. To examine the respective relationship, we conduct a panel data set of 113 countries that includes both developed and developing countries between 2002 and 2015. The GMM dynamic panel estimator developed by Arellano and Bond (1991) is utilized in the estimations, which permits us to control for potential endogeneity between the main dependent variable and the independent variables.

The results suggest that knowledge spillovers due to FDI and patents contribute to sophistication of exports only when sufficient absorptive capacity is available in the host country. The main findings in this paper show that patents seem to be a more influential channel than FDI in terms of contributing to the level of export sophistication. Specifically, patents can increase sophistication of exports for all countries; however, FDI can serve as a channel for knowledge spillovers to benefit the sophistication level of exports only for developed countries. This paradoxical result may be attributed to the worse investment climate and government policies in developing countries. As reported in OECD (2001), the impact of FDI would be smaller in developing countries due to "threshold externalities" and developing countries must have reached a certain level of education, technology and infrastructure before taking advantage of foreign assets.

Indeed, the results suggest that countries' level of financial development can affect the gains from FDIs in terms of exporting more sophisticated goods. While FDI in financially more developed countries increases export sophistication, it is not sufficient 
to improve the sophistication level for less financially developed countries. Notably, the education level also seems to be an important criterion in determining the impact of knowledge spillovers due to FDI. In societies where tertiary education levels are higher, it is more likely that both innovations and FDI increase export sophistication; however, there is no evidence of an impact for countries with lower education levels. Moreover, the findings suggest that countries' globalization level is an important factor for the effect of FDI in improving sophistication of exports. The more globalized countries are more likely to produce and export more sophisticated goods. However, in the less developed countries, increases in FDI do not appear to enhance export sophistication.

In this study, results should not be generalized in terms of the impact of knowledge spillovers on export sophistication as knowledge spillover channels are not limited to FDI and patent applications. Hence, future research can focus on other spillover channels. In addition, a firm-level analysis can provide clearer results for the relationship between FDI, patent applications and export sophistication. Besides, if possible, patent citation data can be used as an alternative knowledge spillover criterion since the effect of international knowledge spillover can be measured more clearly (see Jaffe and Trajtenberg, 1999). Finally, the complexity index developed by Hidalgo and Hausmann (2009), which shows how complex a country's export basket is, can be used as another export quality indicator. 
Appendix

Table 6: GMM estimates on sophistication of exports for all countries: robustness check

\begin{tabular}{|c|c|c|c|c|c|c|}
\hline & (1) & (2) & (3) & (4) & (5) & (6) \\
\hline L.Sophex & $\begin{array}{l}-0.0914 \\
(0.0828)\end{array}$ & $\begin{array}{c}-0.0906 \\
(0.0762)\end{array}$ & $\begin{array}{l}-0.0928 \\
(0.0698)\end{array}$ & $\begin{array}{l}-0.0906 \\
(0.0764)\end{array}$ & $\begin{array}{l}-0.0863 \\
(0.0764)\end{array}$ & $\begin{array}{l}-0.0923 \\
(0.0725)\end{array}$ \\
\hline L.GDP & $\begin{array}{l}0.00326 \\
(0.0387)\end{array}$ & $\begin{array}{l}-0.0268 \\
(0.0288)\end{array}$ & $\begin{array}{l}-0.0370 \\
(0.0269)\end{array}$ & $\begin{array}{l}-0.0201 \\
(0.0267)\end{array}$ & $\begin{array}{l}-0.0179 \\
(0.0262)\end{array}$ & $\begin{array}{l}-0.0289 \\
(0.0286)\end{array}$ \\
\hline L.Patent & $\begin{array}{l}\mathbf{0 . 0 3 0 3 * *} \\
(0.0118)\end{array}$ & $\begin{array}{l}\mathbf{0 . 0 3 0 2} * * * \\
(0.0113)\end{array}$ & $\begin{array}{l}\mathbf{0 . 0 2 9 9 * *} \\
(0.0118)\end{array}$ & $\begin{array}{l}\mathbf{0 . 0 3 0 3} \text { *** } \\
(0.0114)\end{array}$ & $\begin{array}{l}\mathbf{0 . 0 3 0 4} * * * \\
(0.0115)\end{array}$ & $\begin{array}{l}\mathbf{0 . 0 3 0 4} * * * \\
(0.0114)\end{array}$ \\
\hline L.FDI & $\begin{array}{l}-0.00318 \\
(0.00337)\end{array}$ & $\begin{array}{l}-0.00283 \\
(0.00366)\end{array}$ & $\begin{array}{l}-0.00244 \\
(0.00384)\end{array}$ & $\begin{array}{l}-0.00276 \\
(0.00353)\end{array}$ & $\begin{array}{l}-0.00292 \\
(0.00363)\end{array}$ & $\begin{array}{l}-0.00304 \\
(0.00377)\end{array}$ \\
\hline L2.FDI & $\begin{array}{r}-\mathbf{0 . 0 0 4 7 5} \\
(0.00344)\end{array}$ & $\begin{array}{c}-\mathbf{0 . 0 0 4 7 6} \\
(0.00357)\end{array}$ & $\begin{array}{c}-\mathbf{0 . 0 0 4 3 0} \\
(0.00364)\end{array}$ & $\begin{array}{c}\mathbf{- 0 . 0 0 4 7 4} \\
(0.00353)\end{array}$ & $\begin{array}{c}-\mathbf{0 . 0 0 4 9 0} \\
(0.00357)\end{array}$ & $\begin{array}{c}-\mathbf{0 . 0 0 4 7 7} \\
(0.00350)\end{array}$ \\
\hline Saving & $\begin{array}{c}0.0179 \\
(0.0143)\end{array}$ & $\begin{array}{c}0.0186 \\
(0.0138)\end{array}$ & $\begin{array}{c}0.0183 \\
(0.0139)\end{array}$ & $\begin{array}{c}0.0184 \\
(0.0135)\end{array}$ & $\begin{array}{c}0.0182 \\
(0.0133)\end{array}$ & $\begin{array}{c}0.0183 \\
(0.0138)\end{array}$ \\
\hline Population & - & $\begin{array}{c}0.151 \\
(0.134)\end{array}$ & $\begin{array}{c}0.172 \\
(0.155)\end{array}$ & $\begin{array}{c}0.141 \\
(0.141)\end{array}$ & $\begin{array}{c}0.129 \\
(0.146)\end{array}$ & $\begin{array}{c}0.151 \\
(0.150)\end{array}$ \\
\hline Law & - & - & $\begin{array}{c}0.0387 \\
(0.0438)\end{array}$ & - & - & - \\
\hline Regulatory & - & - & - & $\begin{array}{l}-0.0214 \\
(0.0349)\end{array}$ & $\begin{array}{l}-0.0216 \\
(0.0349)\end{array}$ & - \\
\hline Deflator & - & - & - & - & $\begin{array}{c}2.00 e-05 \\
(0.000252)\end{array}$ & $\begin{array}{c}5.75 e-05 \\
(0.000257)\end{array}$ \\
\hline Stability & - & - & - & - & - & $\begin{array}{c}0.0104 \\
(0.0190)\end{array}$ \\
\hline Constant & $\begin{array}{l}10.49 * * * \\
(1.034)\end{array}$ & $\begin{array}{l}8.234^{* * *} \\
(2.736)\end{array}$ & $\begin{array}{l}7.984^{* * *} \\
(2.982)\end{array}$ & $\begin{array}{l}8.344^{* * *} \\
(2.844)\end{array}$ & $\begin{array}{l}8.478^{* * *} \\
(2.921)\end{array}$ & $\begin{array}{l}8.271^{* * *} \\
(2.887)\end{array}$ \\
\hline Observations & 679 & 679 & 679 & 679 & 679 & 679 \\
\hline Number of id & 86 & 86 & 86 & 86 & 86 & 86 \\
\hline
\end{tabular}

Note: Robust standard errors are in brackets. ${ }^{* * *},{ }^{* *}$ and ${ }^{*}$ indicate statistical significance at the $1 \%, 5 \%$ and $10 \%$ level, respectively.

Source: Authors' calculations. 
Table 7: GMM estimates on sophistication of exports for developed and developing countries: robustness check

\begin{tabular}{|c|c|c|c|c|c|c|c|c|c|c|c|c|}
\hline & (1) & (2) & (3) & (4) & (5) & (6) & (7) & (8) & (9) & (10) & (11) & (12) \\
\hline & Developed & Developing & Developed & Developing & Developed & Developing & Developed & Developing & Developed & Developing & Developed & Developing \\
\hline L.Sophex & $\begin{array}{l}0.559 * * * \\
(0.139)\end{array}$ & $\begin{array}{c}-0.0382 \\
(0.125)\end{array}$ & $\begin{array}{l}0.443^{* * *} \\
(0.124)\end{array}$ & $\begin{array}{c}-0.0463 \\
(0.104)\end{array}$ & $\begin{array}{l}0.447^{* * *} \\
(0.119)\end{array}$ & $\begin{array}{l}-0.0526 \\
(0.0904)\end{array}$ & $\begin{array}{l}0.440^{* * *} \\
(0.122)\end{array}$ & $\begin{array}{c}-0.0467 \\
(0.105)\end{array}$ & $\begin{array}{l}0.438^{* * *} \\
(0.124)\end{array}$ & $\begin{array}{c}-0.0465 \\
(0.105)\end{array}$ & $\begin{array}{l}0.435^{* * *} \\
(0.125)\end{array}$ & $\begin{array}{c}-0.0559 \\
(\mathbf{0 . 1 0 0 )}\end{array}$ \\
\hline L.GDP & $\begin{array}{l}0.00541 \\
(0.0215)\end{array}$ & $\begin{array}{c}0.0226 \\
(0.0471)\end{array}$ & $\begin{array}{c}0.0196 \\
(0.0184)\end{array}$ & $\begin{array}{c}-0.0785^{*} \\
(0.0416)\end{array}$ & $\begin{array}{c}0.0140 \\
(0.0139)\end{array}$ & $\begin{array}{c}-0.0896^{* *} \\
(0.0395)\end{array}$ & $\begin{array}{c}0.0187 \\
(0.0187)\end{array}$ & $\begin{array}{l}-0.0612 \\
(0.0395)\end{array}$ & $\begin{array}{c}0.0181 \\
(0.0189)\end{array}$ & $\begin{array}{r}-0.0583 \\
(0.0392)\end{array}$ & $\begin{array}{c}0.0214 \\
(0.0190)\end{array}$ & $\begin{array}{c}-0.0839^{* *} \\
(0.0424)\end{array}$ \\
\hline L.Patent & $\begin{array}{l}\mathbf{0 . 0 0 8 8 6 * *} \\
(0.00442)\end{array}$ & $\begin{array}{l}\mathbf{0 . 0 3 2 1} \text { ** } \\
(0.0147)\end{array}$ & $\begin{array}{l}\mathbf{0 . 0 0 9 3 5 *} \\
(0.00492)\end{array}$ & $\begin{array}{l}\mathbf{0 . 0 3 3 1 * *} \\
(0.0131)\end{array}$ & $\begin{array}{c}\mathbf{0 . 0 0 9 0 5 *} \\
(0.00511)\end{array}$ & $\begin{array}{l}\mathbf{0 . 0 3 2 4}^{* * *} \\
(0.0140)\end{array}$ & $\begin{array}{l}\mathbf{0 . 0 0 9 7 2 *}^{*} \\
(0.00508)\end{array}$ & $\begin{array}{c}\mathbf{0 . 0 3 3 6 * *} \\
(0.0135)\end{array}$ & $\begin{array}{l}\mathbf{0 . 0 0 9 7 4 *} \\
(0.00527)\end{array}$ & $\begin{array}{l}\mathbf{0 . 0 3 4 4}^{* * *} \\
(0.0137)\end{array}$ & $\begin{array}{l}\mathbf{0 . 0 0 9 8 6 *} \\
(0.00510)\end{array}$ & $\begin{array}{l}0.0338^{* *} \\
(0.0134)\end{array}$ \\
\hline L.FDI & $\begin{array}{c}0.00124 \\
(0.000978)\end{array}$ & $\begin{array}{c}-0.0100 \\
(0.00776)\end{array}$ & $\begin{array}{c}0.00132 \\
(0.00101)\end{array}$ & $\begin{array}{l}-0.00987 \\
(0.00865)\end{array}$ & $\begin{array}{c}0.00142 \\
(0.000875)\end{array}$ & $\begin{array}{c}-0.00919 \\
(0.00889)\end{array}$ & $\begin{array}{c}0.00130 \\
(0.000996)\end{array}$ & $\begin{array}{l}-0.00941 \\
(0.00815)\end{array}$ & $\begin{array}{c}0.00134 \\
(0.000988)\end{array}$ & $\begin{array}{l}-0.00975 \\
(0.00832)\end{array}$ & $\begin{array}{c}0.00144 \\
(0.000966)\end{array}$ & $\begin{array}{c}-0.00994 \\
(0.00878)\end{array}$ \\
\hline L2.FDI & $\begin{array}{l}\mathbf{0 . 0 0 3 1 7 * *}^{* *} \\
(0.00136)\end{array}$ & $\begin{array}{c}-0.0178^{* *} \\
(0.00848)\end{array}$ & $\begin{array}{l}\mathbf{0 . 0 0 3 1 6 * *}^{* *} \\
(0.00132)\end{array}$ & $\begin{array}{l}-0.0199 * * \\
(0.00935)\end{array}$ & $\begin{array}{l}\mathbf{0 . 0 0 3 2 0 * *} \\
(0.00131)\end{array}$ & $\begin{array}{c}-0.0185^{*} \\
(0.00985)\end{array}$ & $\begin{array}{l}\mathbf{0 . 0 0 3 1 4} * * \\
(0.00133)\end{array}$ & $\begin{array}{c}-0.0203^{* *} \\
(0.00958)\end{array}$ & $\begin{array}{l}\mathbf{0 . 0 0 3 1 7 * *} \\
(0.00135)\end{array}$ & $\begin{array}{l}-\mathbf{0 . 0 2 0 6 * *} \\
(0.00970)\end{array}$ & $\begin{array}{l}\mathbf{0 . 0 0 3 2 8}^{* *} \\
(0.00132)\end{array}$ & $\begin{array}{c}-0.0194^{* *} \\
(0.00915)\end{array}$ \\
\hline Saving & $\begin{array}{c}0.0300^{* * *} \\
(0.00662)\end{array}$ & $\begin{array}{c}0.0145 \\
(0.0146)\end{array}$ & $\begin{array}{c}0.0170^{* * *} \\
(0.00783)\end{array}$ & $\begin{array}{c}0.0162 \\
(0.0138)\end{array}$ & $\begin{array}{c}0.0155^{* *} \\
(0.00701)\end{array}$ & $\begin{array}{c}0.0163 \\
(0.0135)\end{array}$ & $\begin{array}{c}0.0170^{* *} \\
(0.00767)\end{array}$ & $\begin{array}{c}0.0157 \\
(0.0132)\end{array}$ & $\begin{array}{c}0.0167 \\
(0.0102)\end{array}$ & $\begin{array}{c}0.0158 \\
(0.0131)\end{array}$ & $\begin{array}{l}0.0208^{*} \\
(0.0118)\end{array}$ & $\begin{array}{c}0.0164 \\
(\mathbf{0 . 0 1 3 9})\end{array}$ \\
\hline Population & - & - & $\begin{array}{c}-0.215^{* *} \\
(0.102)\end{array}$ & $\begin{array}{c}0.417 * * * \\
(0.147)\end{array}$ & $\begin{array}{c}-0.215^{* *} \\
(0.102)\end{array}$ & $\begin{array}{l}0.443^{* * *} \\
(0.163)\end{array}$ & $\begin{array}{c}-0.210^{* *} \\
(0.101)\end{array}$ & $\begin{array}{l}0.389^{* * *} \\
(0.142)\end{array}$ & $\begin{array}{c}-0.212^{* *} \\
(0.101)\end{array}$ & $\begin{array}{c}0.362^{* *} \\
(0.146)\end{array}$ & $\begin{array}{c}-0.208^{* *} \\
(0.103)\end{array}$ & $\begin{array}{l}0.414^{* * *} \\
(\mathbf{0 . 1 5 8 )}\end{array}$ \\
\hline Law & - & - & - & - & $\begin{array}{c}0.0121 \\
(0.0234)\end{array}$ & $\begin{array}{c}0.0457 \\
(0.0515)\end{array}$ & - & - & - & - & - & - \\
\hline Regulatory & - & - & - & - & - & - & $\begin{array}{c}0.00121 \\
(0.00855)\end{array}$ & $\begin{array}{l}-0.0438 \\
(0.0506)\end{array}$ & $\begin{array}{c}0.00118 \\
(0.00841)\end{array}$ & $\begin{array}{l}-0.0453 \\
(0.0514)\end{array}$ & - & - \\
\hline Deflator & - & - & - & - & - & - & - & - & $\begin{array}{c}-5.29 \mathrm{e}-05 \\
(0.000421)\end{array}$ & $\begin{array}{l}-0.000303 \\
(0.000248)\end{array}$ & $\begin{array}{l}-7.09 e-05 \\
(0.000434)\end{array}$ & $\begin{array}{c}-0.000216 \\
(\mathbf{0 . 0 0 0 2 3 6 )}\end{array}$ \\
\hline Stability & - & - & - & - & - & - & - & - & - & - & $\begin{array}{r}-0.00870 \\
(0.00712)\end{array}$ & $\begin{array}{c}0.0184 \\
(\mathbf{0 . 0 1 9 2 )}\end{array}$ \\
\hline Constant & $\begin{array}{l}4.186^{* * *} \\
(\mathbf{1 . 1 9 7 )}\end{array}$ & $\begin{array}{l}9.743^{* * *} \\
(1.421)\end{array}$ & $\begin{array}{l}8.756^{* * * *} \\
(\mathbf{1 . 4 1 6 )}\end{array}$ & $\begin{array}{c}3.595 \\
(\mathbf{2 . 7 6 3 )}\end{array}$ & $\begin{array}{l}8.764^{* * *} \\
(\mathbf{1 . 3 8 9 )}\end{array}$ & $\begin{array}{c}3.320 \\
(3.021)\end{array}$ & $\begin{array}{l}8.722^{* * *} \\
(\mathbf{1 . 4 2 2})\end{array}$ & $\begin{array}{c}3.923 \\
(2.795)\end{array}$ & $\begin{array}{l}8.768^{* * *} \\
(\mathbf{1 . 4 6 7 )}\end{array}$ & $\begin{array}{c}4.351 \\
(\mathbf{2 . 9 2 6 )}\end{array}$ & $\begin{array}{l}8.687^{* * *} \\
(\mathbf{1 . 4 5 3 )}\end{array}$ & $\begin{array}{c}3.793 \\
\mathbf{( 2 . 9 3 8 )}\end{array}$ \\
\hline Observations & 276 & 403 & 276 & 403 & 276 & 403 & 276 & 403 & 276 & 403 & 276 & 403 \\
\hline Number of id & 32 & 54 & 32 & 54 & 32 & 54 & 32 & 54 & 32 & 54 & 32 & 54 \\
\hline
\end{tabular}

Note: Robust standard errors are in brackets. ${ }^{* *}, * *$ and * indicate statistical significance at the $1 \%, 5 \%$ and $10 \%$ level, respectively.

Source: Authors' calculations. 
Table 8: GMM estimates on sophistication of exports for more financially developed and less financially developed countries where financial development indicator is "Private credit by deposit money banks to GDP": robustness check

\begin{tabular}{|c|c|c|c|c|c|c|c|c|c|c|c|c|}
\hline & (1) & (2) & (3) & (4) & (5) & (6) & (7) & (8) & (9) & (10) & (11) & (12) \\
\hline & $\begin{array}{c}\text { More } \\
\text { Financially } \\
\text { Developed }\end{array}$ & $\begin{array}{l}\text { Less } \\
\text { Financially } \\
\text { Developed }\end{array}$ & \begin{tabular}{c|} 
More \\
Financially \\
Developed \\
\end{tabular} & $\begin{array}{l}\text { Less } \\
\text { Financially } \\
\text { Developed } \\
\end{array}$ & \begin{tabular}{|c|} 
More \\
Financially \\
Developed \\
\end{tabular} & $\begin{array}{l}\text { Less } \\
\text { Financially } \\
\text { Developed } \\
\end{array}$ & $\begin{array}{c}\text { More } \\
\text { Financially } \\
\text { Developed }\end{array}$ & \begin{tabular}{c|} 
Less \\
Financially \\
Developed \\
\end{tabular} & $\begin{array}{c}\text { More } \\
\text { Financially } \\
\text { Developed }\end{array}$ & $\begin{array}{l}\text { Less } \\
\text { Financially } \\
\text { Developed } \\
\end{array}$ & $\begin{array}{c}\text { More } \\
\text { Financially } \\
\text { Developed }\end{array}$ & $\begin{array}{l}\text { Less } \\
\text { Financially } \\
\text { Developed }\end{array}$ \\
\hline L.Sophex & $\begin{array}{l}0.363^{* *} \\
(0.147)\end{array}$ & $\begin{array}{c}-0.0783 \\
(0.135)\end{array}$ & $\begin{array}{l}0.328^{* * *} \\
(0.167)\end{array}$ & $\begin{array}{c}-0.0793 \\
(0.130)\end{array}$ & $\begin{array}{c}0.325^{*} \\
(0.168)\end{array}$ & $\begin{array}{c}-0.0803 \\
(0.120)\end{array}$ & $\begin{array}{c}0.315^{*} \\
(0.170)\end{array}$ & $\begin{array}{c}-0.0828 \\
(0.131)\end{array}$ & $\begin{array}{c}0.327^{*} \\
(0.174)\end{array}$ & $\begin{array}{c}-0.0804 \\
(0.132)\end{array}$ & $\begin{array}{l}0.336^{*} \\
(0.173)\end{array}$ & $\begin{array}{c}-0.0845 \\
(0.126)\end{array}$ \\
\hline L.GDP & $\begin{array}{c}0.0356 \\
(0.0357) \\
\end{array}$ & $\begin{array}{l}-0.0123 \\
(0.0634) \\
\end{array}$ & $\begin{array}{c}-0.00535 \\
(0.0241)\end{array}$ & $\begin{array}{l}-0.0305 \\
(0.0433) \\
\end{array}$ & $\begin{array}{l}-0.0141 \\
(0.0219) \\
\end{array}$ & $\begin{array}{l}-0.0427 \\
(0.0352) \\
\end{array}$ & $\begin{array}{c}-0.00890 \\
(0.0231) \\
\end{array}$ & $\begin{array}{c}-0.00245 \\
(0.0374) \\
\end{array}$ & $\begin{array}{c}-0.00764 \\
(0.0233) \\
\end{array}$ & $\begin{array}{c}-0.000911 \\
(0.0373)\end{array}$ & $\begin{array}{c}-0.00379 \\
(0.0246)\end{array}$ & $\begin{array}{l}-0.0445 \\
(0.0440) \\
\end{array}$ \\
\hline L.Patent & $\begin{array}{l}\mathbf{0 . 0 2 3 1 * *} \\
(0.0113) \\
\end{array}$ & $\begin{array}{c}\mathbf{0 . 0 3 0 8} * * * \\
(0.00904)\end{array}$ & $\begin{array}{l}\mathbf{0 . 0 2 4 1}^{* *} \\
(0.0111)\end{array}$ & $\begin{array}{c}\mathbf{0 . 0 3 0 2}^{* * * *} \\
(0.00901)\end{array}$ & $\begin{array}{l}\mathbf{0 . 0 2 5 2}^{* *} \\
(0.0105) \\
\end{array}$ & $\begin{array}{l}\mathbf{0 . 0 2 9 5 * * *} \\
(0.0102)\end{array}$ & $\begin{array}{l}\mathbf{0 . 0 2 4 4} * * \\
(0.0106)\end{array}$ & $\begin{array}{l}\mathbf{0 . 0 3 1 0}^{* * * *} \\
(0.00971) \\
\end{array}$ & $\begin{array}{l}\mathbf{0 . 0 2 4 2 * *} \\
(0.0109)\end{array}$ & $\begin{array}{l}\mathbf{0 . 0 3 1 5} * * * \\
(0.0101)\end{array}$ & $\begin{array}{l}\mathbf{0 . 0 2 4 0 * *} \\
(0.0113)\end{array}$ & $\begin{array}{l}\mathbf{0 . 0 3 0 3} \text { **** } \\
(0.00933)\end{array}$ \\
\hline L.FDI & $\begin{array}{c}0.00100 \\
(0.00119)\end{array}$ & $\begin{array}{c}-0.0102 \\
(0.00869)\end{array}$ & $\begin{array}{c}0.00139 \\
(0.00106)\end{array}$ & $\begin{array}{c}-0.0103 \\
(0.00894)\end{array}$ & $\begin{array}{c}0.00143 \\
(0.00112)\end{array}$ & $\begin{array}{l}-0.00964 \\
(0.00924)\end{array}$ & $\begin{array}{c}0.00140 \\
(0.00103)\end{array}$ & $\begin{array}{l}-0.00988 \\
(0.00845)\end{array}$ & $\begin{array}{c}0.00136 \\
(0.00101)\end{array}$ & $\begin{array}{l}-0.00998 \\
(0.00846)\end{array}$ & $\begin{array}{c}0.00132 \\
(0.00104)\end{array}$ & $\begin{array}{c}-0.0102 \\
(0.00912)\end{array}$ \\
\hline L2.FDI & $\begin{array}{l}\mathbf{0 . 0 0 2 7 8} \\
(0.00169) \\
\end{array}$ & $\begin{array}{l}-\mathbf{0 . 0 1 8 3} * * \\
(0.00882) \\
\end{array}$ & $\begin{array}{l}\mathbf{0 . 0 0 3 1 4} * * \\
(0.00156)\end{array}$ & $\begin{array}{c}-\mathbf{0 . 0 1 9 8 * *} \\
(0.00915) \\
\end{array}$ & $\begin{array}{l}\mathbf{0 . 0 0 3 2 1}^{* *} \\
(0.00157) \\
\end{array}$ & $\begin{array}{l}-\mathbf{0 . 0 1 8 8} * * \\
(0.00945)\end{array}$ & $\begin{array}{l}\mathbf{0 . 0 0 3 1 2 *} \\
(0.00163)\end{array}$ & $\begin{array}{l}-0.0197^{* *} \\
(0.00917)\end{array}$ & $\begin{array}{l}\mathbf{0 . 0 0 3 0 3}^{*} \\
(0.00157)\end{array}$ & $\begin{array}{c}-0.0200 * * \\
(0.00924)\end{array}$ & $\begin{array}{l}\mathbf{0 . 0 0 3 0 4 * *} \\
(0.00152)\end{array}$ & $\begin{array}{c}-0.0191 * * \\
(0.00856)\end{array}$ \\
\hline Saving & $\begin{array}{c}0.0144^{* *} \\
(0.00717) \\
\end{array}$ & $\begin{array}{c}0.0273 \\
(0.0298) \\
\end{array}$ & $\begin{array}{c}0.0158^{* *} \\
(0.00670) \\
\end{array}$ & $\begin{array}{c}0.0303 \\
(0.0276) \\
\end{array}$ & $\begin{array}{c}0.0164^{* * *} \\
(0.00719) \\
\end{array}$ & $\begin{array}{c}0.0295 \\
(0.0282) \\
\end{array}$ & $\begin{array}{r}0.0155^{* *} \\
(0.00682) \\
\end{array}$ & $\begin{array}{c}0.0285 \\
(0.0258) \\
\end{array}$ & $\begin{array}{c}0.0157^{* * *} \\
(0.00573)\end{array}$ & $\begin{array}{c}0.0289 \\
(0.0262) \\
\end{array}$ & $\begin{array}{c}0.0160^{* * *} \\
(0.00558)\end{array}$ & $\begin{array}{c}0.0301 \\
(0.0287) \\
\end{array}$ \\
\hline Population & - & - & $\begin{array}{c}0.158^{*} \\
(0.0828) \\
\end{array}$ & $\begin{array}{c}0.137 \\
(0.254) \\
\end{array}$ & $\begin{array}{c}0.151^{*} \\
(0.0777) \\
\end{array}$ & $\begin{array}{c}0.166 \\
(0.298) \\
\end{array}$ & $\begin{array}{c}0.155^{* *} \\
(0.0779) \\
\end{array}$ & $\begin{array}{l}0.0799 \\
(0.281) \\
\end{array}$ & $\begin{array}{c}0.138 \\
(0.0846) \\
\end{array}$ & $\begin{array}{l}0.0636 \\
(0.290) \\
\end{array}$ & $\begin{array}{c}0.143 \\
(0.0884) \\
\end{array}$ & $\begin{array}{c}0.145 \\
(0.277) \\
\end{array}$ \\
\hline Law & - & - & - & - & $\begin{array}{c}0.0452^{* *} \\
(0.0217)\end{array}$ & $\begin{array}{c}0.0369 \\
(0.0709)\end{array}$ & - & - & - & - & - & - \\
\hline Regulatory & - & - & - & - & - & - & $\begin{array}{l}0.0224^{* *} \\
(0.0114)\end{array}$ & $\begin{array}{l}-0.0579 \\
(0.0680)\end{array}$ & $\begin{array}{l}0.0209^{*} \\
(0.0113)\end{array}$ & $\begin{array}{l}-0.0586 \\
(0.0685)\end{array}$ & - & - \\
\hline Deflator & - & - & - & - & - & - & - & - & $\begin{array}{l}-0.000476 \\
(0.000744) \\
\end{array}$ & $\begin{array}{l}-0.000185 \\
(0.000245) \\
\end{array}$ & $\begin{array}{l}-0.000468 \\
(0.000736) \\
\end{array}$ & $\begin{array}{l}-7.22 \mathrm{e}-05 \\
(0.000234) \\
\end{array}$ \\
\hline Stability & - & - & - & - & - & - & - & - & - & - & $\begin{array}{c}0.00226 \\
(0.00883) \\
\end{array}$ & $\begin{array}{c}0.0161 \\
(0.0300) \\
\end{array}$ \\
\hline Constant & $\begin{array}{l}5.788^{* * * *} \\
(1.437)\end{array}$ & $\begin{array}{l}10.42^{* * *} \\
(1.724)\end{array}$ & $\begin{array}{l}3.876^{* *} \\
(1.817) \\
\end{array}$ & $\begin{array}{c}8.271 \\
(5.272) \\
\end{array}$ & $\begin{array}{l}4.053^{* *} \\
(1.801)\end{array}$ & $\begin{array}{c}7.915 \\
(5.838) \\
\end{array}$ & $\begin{array}{l}4.077^{* *} \\
(1.874)\end{array}$ & $\begin{array}{c}9.015 \\
(5.715) \\
\end{array}$ & $\begin{array}{l}4.237^{* *} \\
(1.789)\end{array}$ & $\begin{array}{c}9.252 \\
(5.871) \\
\end{array}$ & $\begin{array}{l}4.041^{* *} \\
(1.708)\end{array}$ & $\begin{array}{c}8.319 \\
(5.450) \\
\end{array}$ \\
\hline Observations & 336 & 332 & 336 & 332 & 336 & 332 & 336 & 332 & 336 & 332 & 336 & 332 \\
\hline Number of id & 47 & 53 & 47 & 53 & 47 & 53 & 47 & 53 & 47 & 53 & 47 & 53 \\
\hline
\end{tabular}

Note: Robust standard errors are in brackets. ${ }^{* * *}, * *$ and ${ }^{*}$ indicate statistical significance at the $1 \%, 5 \%$ and $10 \%$ level, respectively.

Here, financial development threshold level is created by using mean values of "Private credit by deposit money banks to GDP" in a given year.

Source: Authors' calculations. 
Table 9: GMM estimates on sophistication of exports for more educated and less educated countries where educational level indicator is "tertiary school enrolment": robustness check

\begin{tabular}{|c|c|c|c|c|c|c|c|c|c|c|c|c|}
\hline & (1) & (2) & (3) & (4) & (5) & (6) & (7) & (8) & (9) & (10) & (11) & $(12)$ \\
\hline & $\begin{array}{c}\text { More } \\
\text { Educated }\end{array}$ & $\begin{array}{c}\text { Less } \\
\text { Educated }\end{array}$ & $\begin{array}{c}\text { More } \\
\text { Educated }\end{array}$ & $\begin{array}{c}\text { Less } \\
\text { Educated }\end{array}$ & $\begin{array}{c}\text { More } \\
\text { Educated }\end{array}$ & $\begin{array}{c}\text { Less } \\
\text { Educated }\end{array}$ & $\begin{array}{c}\text { More } \\
\text { Educated }\end{array}$ & $\begin{array}{c}\text { Less } \\
\text { Educated }\end{array}$ & $\begin{array}{c}\text { More } \\
\text { Educated }\end{array}$ & $\begin{array}{c}\text { Less } \\
\text { Educated }\end{array}$ & $\begin{array}{c}\text { More } \\
\text { Educated }\end{array}$ & $\begin{array}{c}\text { Less } \\
\text { Educated }\end{array}$ \\
\hline L.Sophex & $\begin{array}{l}0.455^{* * *} \\
(0.0819)\end{array}$ & $\begin{array}{c}-0.139 \\
(0.0870)\end{array}$ & $\begin{array}{l}0.447^{* * *} \\
(0.0792)\end{array}$ & $\begin{array}{c}-0.124 \\
(0.0926)\end{array}$ & $\begin{array}{l}0.434 * * * \\
(0.0794)\end{array}$ & $\begin{array}{c}-0.119 \\
(0.0886)\end{array}$ & $\begin{array}{l}0.443^{* * *} \\
(0.0793)\end{array}$ & $\begin{array}{c}-0.122 \\
(0.0929)\end{array}$ & $\begin{array}{l}0.462^{* * *} \\
(0.0810)\end{array}$ & $\begin{array}{c}-0.124 \\
(0.0927)\end{array}$ & $\begin{array}{l}0.466^{* * *} \\
(0.0810)\end{array}$ & $\begin{array}{c}-0.118 \\
(0.0798)\end{array}$ \\
\hline L.GDP & $\begin{array}{l}-0.0113 \\
(0.0194)\end{array}$ & $\begin{array}{l}-0.0415 \\
(0.0942)\end{array}$ & $\begin{array}{c}-0.00791 \\
(0.0165)\end{array}$ & $\begin{array}{c}-0.102 \\
(0.0820)\end{array}$ & $\begin{array}{l}-0.0172 \\
(0.0143)\end{array}$ & $\begin{array}{c}-0.110 \\
(0.0673)\end{array}$ & $\begin{array}{c}-0.00917 \\
(0.0163)\end{array}$ & $\begin{array}{l}-0.0757 \\
(0.0617)\end{array}$ & $\begin{array}{l}-0.0101 \\
(0.0159)\end{array}$ & $\begin{array}{l}-0.0722 \\
(0.0597)\end{array}$ & $\begin{array}{c}-0.00818 \\
(0.0164)\end{array}$ & $\begin{array}{l}-0.0879 \\
(0.0712)\end{array}$ \\
\hline L.Patent & $\begin{array}{l}\mathbf{0 . 0 1 1 7 * *} \\
(0.00501)\end{array}$ & $\begin{array}{l}\mathbf{0 . 0 2 7 1} \\
(0.0177)\end{array}$ & $\begin{array}{l}\mathbf{0 . 0 1 1 6 * * *} \\
(0.00497)\end{array}$ & $\begin{array}{l}\mathbf{0 . 0 2 6 2} \\
(0.0168)\end{array}$ & $\begin{array}{l}\mathbf{0 . 0 1 2 0 * * *} \\
(0.00496)\end{array}$ & $\begin{array}{l}\mathbf{0 . 0 2 5 3} \\
(0.0169)\end{array}$ & $\begin{array}{l}\mathbf{0 . 0 1 2 3} * * \\
(0.00502)\end{array}$ & $\begin{array}{l}\mathbf{0 . 0 2 7 4} \\
(0.0181)\end{array}$ & $\begin{array}{l}\mathbf{0 . 0 1 2 2}^{* * *} \\
(0.00500)\end{array}$ & $\begin{array}{l}\mathbf{0 . 0 2 7 7} \\
(0.0174)\end{array}$ & $\begin{array}{c}\mathbf{0 . 0 1 1 5 * *} \\
(0.00494)\end{array}$ & $\begin{array}{l}\text { 0.0266* } \\
(0.0157)\end{array}$ \\
\hline L.FDI & $\begin{array}{c}0.00142 \\
(0.000965) \\
\end{array}$ & $\begin{array}{l}-0.00403 \\
(0.00896) \\
\end{array}$ & $\begin{array}{c}0.00135 \\
(0.000915) \\
\end{array}$ & $\begin{array}{l}-0.00604 \\
(0.00880) \\
\end{array}$ & $\begin{array}{l}0.00163^{* *} \\
(0.000825) \\
\end{array}$ & $\begin{array}{l}-0.00493 \\
(0.00867) \\
\end{array}$ & $\begin{array}{c}0.00130 \\
(0.000909) \\
\end{array}$ & $\begin{array}{l}-0.00513 \\
(0.00762) \\
\end{array}$ & $\begin{array}{c}0.00146 \\
(0.000895) \\
\end{array}$ & $\begin{array}{l}-0.00523 \\
(0.00773) \\
\end{array}$ & $\begin{array}{c}0.00146 \\
(0.000896) \\
\end{array}$ & $\begin{array}{c}-0.00708 \\
(0.0103) \\
\end{array}$ \\
\hline L2.FDI & $\begin{array}{l}\mathbf{0 . 0 0 3 7 0 * * *} \\
(0.00142)\end{array}$ & $\begin{array}{c}-\mathbf{0 . 0 2 0 5 *} \\
(0.0111)\end{array}$ & $\begin{array}{l}\mathbf{0 . 0 0 3 6 9 * * *} \\
(0.00140)\end{array}$ & $\begin{array}{c}-0.0226 * \\
(0.0120)\end{array}$ & $\begin{array}{c}\mathbf{0 . 0 0 3 8 0 * * * *} \\
(0.00137)\end{array}$ & $\begin{array}{c}-0.0214 * \\
(0.0126)\end{array}$ & $\begin{array}{l}\mathbf{0 . 0 0 3 6 0 * *} \\
(0.00145)\end{array}$ & $\begin{array}{c}-0.0235^{*} \\
(0.0124)\end{array}$ & $\begin{array}{l}\mathbf{0 . 0 0 3 5 5 * *} \\
(0.00145)\end{array}$ & $\begin{array}{c}-\mathbf{0 . 0 2 3 5 *} \\
(0.0124)\end{array}$ & $\begin{array}{l}\mathbf{0 . 0 0 3 6 1 * * * *} \\
(0.00140)\end{array}$ & $\begin{array}{c}-\mathbf{0 . 0 2 3 4} * \\
(0.0127)\end{array}$ \\
\hline Saving & $\begin{array}{c}0.0120^{* * *} \\
(0.00465)\end{array}$ & $\begin{array}{c}0.0456 \\
(0.0382)\end{array}$ & $\begin{array}{c}0.0115^{* * *} \\
(0.00427)\end{array}$ & $\begin{array}{c}0.0505 \\
(0.0367) \\
\end{array}$ & $\begin{array}{c}0.0110 * * * \\
(0.00387) \\
\end{array}$ & $\begin{array}{c}0.0482 \\
(0.0363) \\
\end{array}$ & $\begin{array}{c}0.0113 * * * \\
(0.00413) \\
\end{array}$ & $\begin{array}{c}0.0500 \\
(0.0360) \\
\end{array}$ & $\begin{array}{c}0.0126 * * * \\
(0.00439) \\
\end{array}$ & $\begin{array}{c}0.0495 \\
(0.0367) \\
\end{array}$ & $\begin{array}{c}0.0127^{* * *} \\
(0.00455) \\
\end{array}$ & $\begin{array}{c}0.0506 \\
(0.0404) \\
\end{array}$ \\
\hline Population & - & - & $\begin{array}{l}-0.0480 \\
(0.0840)\end{array}$ & $\begin{array}{c}0.334 \\
(0.344)\end{array}$ & $\begin{array}{l}-0.0489 \\
(0.0800)\end{array}$ & $\begin{array}{c}0.374 \\
(0.463)\end{array}$ & $\begin{array}{l}-0.0509 \\
(0.0801)\end{array}$ & $\begin{array}{c}0.271 \\
(0.377)\end{array}$ & $\begin{array}{l}-0.0531 \\
(0.0784)\end{array}$ & $\begin{array}{c}0.250 \\
(0.373)\end{array}$ & $\begin{array}{l}-0.0499 \\
(0.0820)\end{array}$ & $\begin{array}{c}0.287 \\
(0.419)\end{array}$ \\
\hline Law & - & - & - & - & $\begin{array}{c}0.0312 \\
(0.0195) \\
\end{array}$ & $\begin{array}{l}0.0186 \\
(0.128) \\
\end{array}$ & - & - & - & - & - & - \\
\hline Regulatory & - & - & - & - & - & - & $\begin{array}{c}0.0130 \\
(0.0117)\end{array}$ & $\begin{array}{l}-0.0499 \\
(0.0891)\end{array}$ & $\begin{array}{c}0.0123 \\
(0.0118)\end{array}$ & $\begin{array}{l}-0.0503 \\
(0.0894)\end{array}$ & - & - \\
\hline Deflator & - & - & - & - & - & - & - & - & $\begin{array}{c}-0.000344^{* *} \\
(0.000142)\end{array}$ & $\begin{array}{l}-0.000222 \\
(0.000580)\end{array}$ & $\begin{array}{c}-0.000339^{* *} \\
(0.000145)\end{array}$ & $\begin{array}{l}-0.000192 \\
(0.000598)\end{array}$ \\
\hline Stability & - & - & - & - & - & - & - & - & - & - & $\begin{array}{l}-0.00210 \\
(0.00788) \\
\end{array}$ & $\begin{array}{l}-0.0122 \\
(0.0568)\end{array}$ \\
\hline Constant & $\begin{array}{l}5.393^{* * *} \\
(0.749)\end{array}$ & $\begin{array}{l}11.21 * * * \\
(1.489)\end{array}$ & $\begin{array}{l}6.230 * * * \\
(1.487)\end{array}$ & $\begin{array}{c}5.724 \\
(6.492)\end{array}$ & $\begin{array}{l}6.444^{* * *} \\
(1.387)\end{array}$ & $\begin{array}{c}5.060 \\
(8.620)\end{array}$ & $\begin{array}{l}6.324^{* * *} \\
(1.478)\end{array}$ & $\begin{array}{c}6.568 \\
(7.099)\end{array}$ & $\begin{array}{l}6.173^{* * *} \\
(1.458)\end{array}$ & $\begin{array}{c}6.923 \\
(7.005)\end{array}$ & $\begin{array}{l}6.077^{* * *} \\
(1.444)\end{array}$ & $\begin{array}{l}6.360 \\
(7.562)\end{array}$ \\
\hline Observations & 332 & 189 & 332 & 189 & 332 & 189 & 332 & 189 & 332 & 189 & 332 & 189 \\
\hline Number of id & 50 & 35 & 50 & 35 & 50 & 35 & 50 & 35 & 50 & 35 & 50 & 35 \\
\hline
\end{tabular}

Note: Robust standard errors are in brackets. ${ }^{* * *},{ }^{* *}$ and ${ }^{*}$ indicate statistical significance at the $1 \%, 5 \%$ and $10 \%$ level, respectively. Note: Here, education threshold level is created by using median values of "tertiary school enrolment" in a given year.

Source: Authors' calculations. 
Table 10: GMM estimates on sophistication of exports for more globalized and less globalized countries: robustness check

\begin{tabular}{|c|c|c|c|c|c|c|c|c|c|c|c|c|}
\hline & (1) & (2) & (3) & (4) & (5) & (6) & (7) & (8) & (9) & (10) & (11) & (12) \\
\hline & $\begin{array}{c}\text { More } \\
\text { Globalized }\end{array}$ & $\begin{array}{c}\text { Less } \\
\text { Globalized }\end{array}$ & $\begin{array}{c}\text { More } \\
\text { Globalized }\end{array}$ & $\begin{array}{c}\text { Less } \\
\text { Globalized }\end{array}$ & $\begin{array}{c}\text { More } \\
\text { Globalized }\end{array}$ & $\begin{array}{c}\text { Less } \\
\text { Globalized }\end{array}$ & $\begin{array}{c}\text { More } \\
\text { Globalized }\end{array}$ & $\begin{array}{c}\text { Less } \\
\text { Globalized }\end{array}$ & $\begin{array}{c}\text { More } \\
\text { Globalized }\end{array}$ & $\begin{array}{c}\text { Less } \\
\text { Globalized }\end{array}$ & $\begin{array}{c}\text { More } \\
\text { Globalized }\end{array}$ & $\begin{array}{c}\text { Less } \\
\text { Globalized }\end{array}$ \\
\hline L.Sophex & $\begin{array}{c}0.302^{* * * *} \\
(0.0806)\end{array}$ & $\begin{array}{c}-0.0477 \\
(0.157)\end{array}$ & $\begin{array}{l}0.282^{* * *} \\
(0.104)\end{array}$ & $\begin{array}{c}-0.0518 \\
(0.141)\end{array}$ & $\begin{array}{l}0.280^{* * *} \\
(0.104)\end{array}$ & $\begin{array}{c}-0.0569 \\
(0.125)\end{array}$ & $\begin{array}{l}0.269^{* *} \\
(0.106)\end{array}$ & $\begin{array}{c}-0.0517 \\
(0.140)\end{array}$ & $\begin{array}{l}0.281^{* *} \\
(0.122)\end{array}$ & $\begin{array}{c}-0.0538 \\
(0.142)\end{array}$ & $\begin{array}{l}0.291^{* *} \\
(0.116)\end{array}$ & $\begin{array}{c}-0.0589 \\
(0.136)\end{array}$ \\
\hline L.GDP & $\begin{array}{c}0.0121 \\
(0.0286)\end{array}$ & $\begin{array}{c}0.0274 \\
(0.0724)\end{array}$ & $\begin{array}{c}-0.00684 \\
(0.0253)\end{array}$ & $\begin{array}{l}-0.0579 \\
(0.0613)\end{array}$ & $\begin{array}{l}-0.0180 \\
(0.0246)\end{array}$ & $\begin{array}{c}-0.0639 \\
(0.0577)\end{array}$ & $\begin{array}{c}-0.00863 \\
(0.0260)\end{array}$ & $\begin{array}{l}-0.0374 \\
(0.0581)\end{array}$ & $\begin{array}{l}-0.0104 \\
(0.0245)\end{array}$ & $\begin{array}{l}-0.0344 \\
(0.0581)\end{array}$ & $\begin{array}{c}-0.00919 \\
(0.0243)\end{array}$ & $\begin{array}{c}-0.0633 \\
(0.0640)\end{array}$ \\
\hline L.Patent & $\begin{array}{c}\mathbf{0 . 0 1 2 3} \\
(0.00655)\end{array}$ & $\begin{array}{l}\mathbf{0 . 0 2 6 8 * *} \\
(0.0134)\end{array}$ & $\begin{array}{c}\mathbf{0 . 0 1 2 1}^{*} \\
(0.00643)\end{array}$ & $\begin{array}{l}\mathbf{0 . 0 2 8 6 * *} \\
(0.0123)\end{array}$ & $\begin{array}{c}\mathbf{0 . 0 1 2 1} * * \\
(0.00617)\end{array}$ & $\begin{array}{l}\mathbf{0 . 0 2 7 7}^{* * *} \\
(0.0131)\end{array}$ & $\begin{array}{c}\mathbf{0 . 0 1 3 1} \text { ** } \\
(0.00666)\end{array}$ & $\begin{array}{l}\mathbf{0 . 0 2 8 9} * * \\
(0.0124)\end{array}$ & $\begin{array}{c}\mathbf{0 . 0 1 2 9 *} \\
(0.00698)\end{array}$ & $\begin{array}{l}\mathbf{0 . 0 2 9 5 * *} \\
(0.0127)\end{array}$ & $\begin{array}{l}\mathbf{0 . 0 1 2 1}^{*} \\
(0.00661)\end{array}$ & $\begin{array}{l}\mathbf{0 . 0 2 9 4}^{* * *} \\
(0.0127)\end{array}$ \\
\hline L.FDI & $\begin{array}{l}0.000805 \\
(0.00115)\end{array}$ & $\begin{array}{l}-0.0139 \\
(0.0121) \\
\end{array}$ & $\begin{array}{c}0.00111 \\
(0.00112)\end{array}$ & $\begin{array}{l}-0.0160 \\
(0.0127)\end{array}$ & $\begin{array}{c}0.00142 \\
(0.00101)\end{array}$ & $\begin{array}{l}-0.0156 \\
(0.0123)\end{array}$ & $\begin{array}{c}0.00106 \\
(0.00110)\end{array}$ & $\begin{array}{l}-0.0143 \\
(0.0112)\end{array}$ & $\begin{array}{c}0.00113 \\
(0.00104)\end{array}$ & $\begin{array}{l}-0.0143 \\
(0.0112)\end{array}$ & $\begin{array}{c}0.00116 \\
(0.00107)\end{array}$ & $\begin{array}{l}-0.0161 \\
(0.0130)\end{array}$ \\
\hline L2.FDI & $\begin{array}{l}\mathbf{0 . 0 0 2 7 5 *} \\
(0.00151)\end{array}$ & $\begin{array}{c}-0.0318 * * * \\
(0.0120)\end{array}$ & $\begin{array}{l}\mathbf{0 . 0 0 2 9 1}^{* *} \\
(0.00148)\end{array}$ & $\begin{array}{c}-\mathbf{0 . 0 3 6 4} * * * \\
(0.0132)\end{array}$ & $\begin{array}{c}\mathbf{0 . 0 0 3 0 0 * *} \\
(0.00146)\end{array}$ & $\begin{array}{c}-\mathbf{0 . 0 3 4 4 * *} \\
(0.0134)\end{array}$ & $\begin{array}{l}\mathbf{0 . 0 0 2 8 4 *} \\
(0.00152)\end{array}$ & $\begin{array}{c}-0.0360 * * * \\
(0.0128)\end{array}$ & $\begin{array}{l}\mathbf{0 . 0 0 2 8 5 *} \\
(0.00150)\end{array}$ & $\begin{array}{c}-0.0362^{* * *} \\
(0.0130)\end{array}$ & $\begin{array}{l}\mathbf{0 . 0 0 2 9 0 * *} \\
(0.00148)\end{array}$ & $\begin{array}{c}-\mathbf{0} .0350 * * * \\
(0.0128)\end{array}$ \\
\hline Saving & $\begin{array}{c}0.0136 * * \\
(0.00662)\end{array}$ & $\begin{array}{c}0.0294 \\
(0.0287)\end{array}$ & $\begin{array}{c}0.0142^{* *} \\
(0.00611)\end{array}$ & $\begin{array}{c}0.0342 \\
(0.0271)\end{array}$ & $\begin{array}{c}0.0146^{* *} \\
(0.00650)\end{array}$ & $\begin{array}{c}0.0329 \\
(0.0277)\end{array}$ & $\begin{array}{c}0.0140 * * \\
(0.00614)\end{array}$ & $\begin{array}{c}0.0330 \\
(0.0258)\end{array}$ & $\begin{array}{c}0.0145^{* * *} \\
(0.00442)\end{array}$ & $\begin{array}{c}0.0337 \\
(0.0263)\end{array}$ & $\begin{array}{c}0.0147^{* * *} \\
(0.00443)\end{array}$ & $\begin{array}{c}0.0330 \\
(0.0289)\end{array}$ \\
\hline Population & - & - & $\begin{array}{c}0.0935 \\
(0.0989)\end{array}$ & $\begin{array}{c}0.374 \\
(0.253)\end{array}$ & $\begin{array}{c}0.0929 \\
(0.0957)\end{array}$ & $\begin{array}{c}0.403 \\
(0.268)\end{array}$ & $\begin{array}{c}0.0872 \\
(0.0959)\end{array}$ & $\begin{array}{c}0.317 \\
(0.264)\end{array}$ & $\begin{array}{l}0.0723 \\
(0.101)\end{array}$ & $\begin{array}{c}0.294 \\
(0.275)\end{array}$ & $\begin{array}{l}0.0785 \\
(0.104)\end{array}$ & $\begin{array}{c}0.368 \\
(0.273)\end{array}$ \\
\hline Law & - & - & - & - & $\begin{array}{c}0.0341 \\
(0.0235)\end{array}$ & $\begin{array}{c}0.0513 \\
(0.0652)\end{array}$ & - & - & - & - & - & - \\
\hline Regulatory & - & - & - & - & - & - & $\begin{array}{c}0.0103 \\
(0.00980)\end{array}$ & $\begin{array}{l}-0.0444 \\
(0.0705)\end{array}$ & $\begin{array}{l}0.00831 \\
(0.0102)\end{array}$ & $\begin{array}{l}-0.0453 \\
(0.0715)\end{array}$ & - & - \\
\hline Deflator & - & - & - & - & - & - & - & - & $\begin{array}{l}-0.000799 \\
(0.000607)\end{array}$ & $\begin{array}{l}-0.000280 \\
(0.000273)\end{array}$ & $\begin{array}{l}-0.000793 \\
(0.000594) \\
\end{array}$ & $\begin{array}{l}-0.000191 \\
(0.000269)\end{array}$ \\
\hline Stability & - & - & - & - & - & - & - & - & - & - & $\begin{array}{c}-0.000258 \\
(0.00901)\end{array}$ & $\begin{array}{c}0.0203 \\
(0.0311) \\
\end{array}$ \\
\hline Constant & $\begin{array}{l}6.666 * * * \\
(0.681)\end{array}$ & $\begin{array}{l}9.748^{* * *} \\
(1.873)\end{array}$ & $\begin{array}{l}5.515^{* * *} \\
(1.128)\end{array}$ & $\begin{array}{c}4.061 \\
(4.916)\end{array}$ & $\begin{array}{l}5.625^{* * *} \\
(1.037)\end{array}$ & $\begin{array}{c}3.700 \\
(5.146)\end{array}$ & $\begin{array}{l}5.748^{* * *} \\
(1.149)\end{array}$ & $\begin{array}{c}4.847 \\
(5.246)\end{array}$ & $\begin{array}{l}5.898^{* * *} \\
(1.129)\end{array}$ & $\begin{array}{c}5.245 \\
(5.499)\end{array}$ & $\begin{array}{l}5.693^{* * *} \\
(1.110)\end{array}$ & $\begin{array}{c}4.296 \\
(5.206)\end{array}$ \\
\hline Observations & 384 & 262 & 384 & 262 & 384 & 262 & 384 & 262 & 384 & 262 & 384 & 262 \\
\hline Number of id & 50 & 41 & 50 & 41 & 50 & 41 & 50 & 41 & 50 & 41 & 50 & 41 \\
\hline
\end{tabular}

Note: Robust standard errors are in brackets. ${ }^{* *},{ }^{* *}$ and ${ }^{*}$ indicate statistical significance at the $1 \%, 5 \%$ and $10 \%$ level, respectively. Note: Here, globalization threshold level is created by using mean values of "KOF Globalization Index" in a given year.

Source: Authors' calculations. 
Table 11: GMM estimates on sophistication of exports for more financially developed and less financially developed countries where financial development indicator is "Private credit by deposit money banks to GDP": alternative robustness check

\begin{tabular}{|c|c|c|c|c|c|c|c|c|c|c|c|c|}
\hline & (1) & (2) & (3) & (4) & (5) & (6) & (7) & (8) & (9) & $(10)$ & (11) & (12) \\
\hline & $\begin{array}{c}\text { More } \\
\text { Financially } \\
\text { Developed }\end{array}$ & $\begin{array}{l}\text { Less } \\
\text { Financially } \\
\text { Developed }\end{array}$ & $\begin{array}{c}\text { More } \\
\text { Financially } \\
\text { Developed }\end{array}$ & $\begin{array}{l}\text { Less } \\
\text { Financially } \\
\text { Developed }\end{array}$ & $\begin{array}{c}\text { More } \\
\text { Financially } \\
\text { Developed }\end{array}$ & $\begin{array}{l}\text { Less } \\
\text { Financially } \\
\text { Developed }\end{array}$ & $\begin{array}{c}\text { More } \\
\text { Financially } \\
\text { Developed }\end{array}$ & $\begin{array}{l}\text { Less } \\
\text { Financially } \\
\text { Developed }\end{array}$ & $\begin{array}{c}\text { More } \\
\text { Financially } \\
\text { Developed }\end{array}$ & $\begin{array}{l}\text { Less } \\
\text { Financially } \\
\text { Developed }\end{array}$ & $\begin{array}{c}\text { More } \\
\text { Financially } \\
\text { Developed }\end{array}$ & $\begin{array}{l}\text { Less } \\
\text { Financially } \\
\text { Developed }\end{array}$ \\
\hline L.Sophex & $\begin{array}{c}0.141 \\
(0.108)\end{array}$ & $\begin{array}{c}-0.0751 \\
(0.169) \\
\end{array}$ & $\begin{array}{c}0.128 \\
(0.115) \\
\end{array}$ & $\begin{array}{c}-0.0804 \\
(0.152) \\
\end{array}$ & $\begin{array}{c}0.117 \\
(0.118) \\
\end{array}$ & $\begin{array}{c}-0.0808 \\
(0.143) \\
\end{array}$ & $\begin{array}{l}0.0993 \\
(0.114) \\
\end{array}$ & $\begin{array}{c}-0.0832 \\
(0.151) \\
\end{array}$ & $\begin{array}{c}0.114 \\
(0.127) \\
\end{array}$ & $\begin{array}{c}-0.0851 \\
(0.154) \\
\end{array}$ & $\begin{array}{c}0.142 \\
(0.130) \\
\end{array}$ & $\begin{array}{c}-0.0872 \\
(0.150) \\
\end{array}$ \\
\hline L.GDP & $\begin{array}{c}0.0292 \\
(0.0322) \\
\end{array}$ & $\begin{array}{c}-0.00903 \\
(0.0814) \\
\end{array}$ & $\begin{array}{l}0.00193 \\
(0.0207) \\
\end{array}$ & $\begin{array}{l}-0.0688 \\
(0.0698) \\
\end{array}$ & $\begin{array}{c}-0.00959 \\
(0.0195) \\
\end{array}$ & $\begin{array}{l}-0.0745 \\
(0.0585) \\
\end{array}$ & $\begin{array}{c}-0.00243 \\
(0.0212) \\
\end{array}$ & $\begin{array}{l}-0.0303 \\
(0.0551) \\
\end{array}$ & $\begin{array}{c}-0.00206 \\
(0.0209) \\
\end{array}$ & $\begin{array}{l}-0.0261 \\
(0.0541) \\
\end{array}$ & $\begin{array}{l}0.00202 \\
(0.0202) \\
\end{array}$ & $\begin{array}{l}-0.0831 \\
(0.0611) \\
\end{array}$ \\
\hline L.Patent & $\begin{array}{c}\mathbf{0 . 0 2 1 2}^{* * *} \\
(0.00930)\end{array}$ & $\begin{array}{l}\mathbf{0 . 0 2 9 3}^{* *} \\
(0.0139) \\
\end{array}$ & $\begin{array}{c}\mathbf{0 . 0 2 2 3}^{* * *} \\
(0.00919)\end{array}$ & $\begin{array}{l}\mathbf{0 . 0 3 0 2}^{* * *} \\
(0.0128) \\
\end{array}$ & $\begin{array}{l}\mathbf{0 . 0 2 3 8}^{* * *} \\
(0.00889)\end{array}$ & $\begin{array}{l}\mathbf{0 . 0 2 9 8 * *} \\
(0.0139) \\
\end{array}$ & $\begin{array}{l}\mathbf{0 . 0 2 2 8}^{* * *} \\
(0.00882)\end{array}$ & $\begin{array}{l}\mathbf{0 . 0 3 1 4} * * \\
(0.0130) \\
\end{array}$ & $\begin{array}{c}\mathbf{0 . 0 2 2 5}^{* * *} \\
(0.00906)\end{array}$ & $\begin{array}{l}\mathbf{0 . 0 3 2 6 * *} \\
(0.0137) \\
\end{array}$ & $\begin{array}{c}\mathbf{0 . 0 2 1 9 * *} \\
(0.00943)\end{array}$ & $\begin{array}{l}\mathbf{0 . 0 3 0 1}^{* * *} \\
(0.0134)\end{array}$ \\
\hline L.FDI & $\begin{array}{l}0.000190 \\
(0.00107) \\
\end{array}$ & $\begin{array}{l}-0.0175 \\
(0.0130) \\
\end{array}$ & $\begin{array}{c}0.000549 \\
(0.000947) \\
\end{array}$ & $\begin{array}{l}-0.0190 \\
(0.0135) \\
\end{array}$ & $\begin{array}{c}0.000865 \\
(0.000859) \\
\end{array}$ & $\begin{array}{l}-0.0188 \\
(0.0132) \\
\end{array}$ & $\begin{array}{c}0.000639 \\
(0.000906) \\
\end{array}$ & $\begin{array}{l}-0.0172 \\
(0.0124) \\
\end{array}$ & $\begin{array}{c}0.000644 \\
(0.000888) \\
\end{array}$ & $\begin{array}{l}-0.0178 \\
(0.0127) \\
\end{array}$ & $\begin{array}{c}0.000574 \\
(0.000928) \\
\end{array}$ & $\begin{array}{l}-0.0189 \\
(0.0140) \\
\end{array}$ \\
\hline L2.FDI & $\begin{array}{l}\mathbf{0 . 0 0 2 6 1 *} \\
(0.00137)\end{array}$ & $\begin{array}{c}-0.0308^{* *} \\
(0.0135)\end{array}$ & $\begin{array}{c}\mathbf{0 . 0 0 2 8 5} * * \\
(0.00128)\end{array}$ & $\begin{array}{c}-0.0357^{* *} \\
(0.0140)\end{array}$ & $\begin{array}{l}\mathbf{0 . 0 0 3 0 1 * *} \\
(0.00127) \\
\end{array}$ & $\begin{array}{c}-\mathbf{0 . 0 3 4 8 * *} \\
(0.0147)\end{array}$ & $\begin{array}{l}\mathbf{0 . 0 0 2 7 7 * *} \\
(0.00138) \\
\end{array}$ & $\begin{array}{c}-0.0360^{* *} \\
(0.0141)\end{array}$ & $\begin{array}{l}\mathbf{0 . 0 0 2 7 6 * *}^{*} \\
(0.00138) \\
\end{array}$ & $\begin{array}{c}-\mathbf{0 . 0 3 6 8 * *} \\
(0.0144)\end{array}$ & $\begin{array}{l}\mathbf{0 . 0 0 2 8 4}^{* *} \\
(0.00129)\end{array}$ & $\begin{array}{c}-\mathbf{0 . 0 3 4 1} \text { **** } \\
(0.0131)\end{array}$ \\
\hline Saving & $\begin{array}{l}0.0119^{* *} \\
(0.00568) \\
\end{array}$ & $\begin{array}{c}0.0261 \\
(0.0309) \\
\end{array}$ & $\begin{array}{c}0.0130^{* *} \\
(0.00517) \\
\end{array}$ & $\begin{array}{c}0.0316 \\
(0.0288) \\
\end{array}$ & $\begin{array}{c}0.0137^{* *} \\
(0.00564)\end{array}$ & $\begin{array}{c}0.0310 \\
(0.0293) \\
\end{array}$ & $\begin{array}{c}0.0128^{* *} \\
(0.00521)\end{array}$ & $\begin{array}{c}0.0293 \\
(0.0271) \\
\end{array}$ & $\begin{array}{c}0.0129^{* * *} \\
(0.00472)\end{array}$ & $\begin{array}{c}0.0301 \\
(0.0276) \\
\end{array}$ & $\begin{array}{c}0.0131^{* * *} \\
(0.00459)\end{array}$ & $\begin{array}{c}0.0321 \\
(0.0304) \\
\end{array}$ \\
\hline Population & - & - & $\begin{array}{c}0.120 \\
(0.109) \\
\end{array}$ & $\begin{array}{c}0.352 \\
(0.274) \\
\end{array}$ & $\begin{array}{c}0.121 \\
(0.105) \\
\end{array}$ & $\begin{array}{c}0.366 \\
(0.291) \\
\end{array}$ & $\begin{array}{c}0.119 \\
(0.103) \\
\end{array}$ & $\begin{array}{c}0.275 \\
(0.267) \\
\end{array}$ & $\begin{array}{c}0.109 \\
(0.110)\end{array}$ & $\begin{array}{c}0.248 \\
(0.276) \\
\end{array}$ & $\begin{array}{c}0.109 \\
(0.116)\end{array}$ & $\begin{array}{c}0.347 \\
(0.288) \\
\end{array}$ \\
\hline Law & - & - & - & - & $\begin{array}{l}0.0455^{* * *} \\
(0.0176) \\
\end{array}$ & $\begin{array}{c}0.0246 \\
(0.0783) \\
\end{array}$ & - & - & - & - & - & - \\
\hline Regulatory & - & - & - & - & - & - & $\begin{array}{l}0.0310^{* * *} \\
(0.0122)\end{array}$ & $\begin{array}{l}-0.0707 \\
(0.0743)\end{array}$ & $\begin{array}{l}0.0295^{* *} \\
(0.0128) \\
\end{array}$ & $\begin{array}{l}-0.0738 \\
(0.0767) \\
\end{array}$ & - & - \\
\hline Deflator & - & - & - & - & - & - & - & - & $\begin{array}{l}-0.000244 \\
(0.000668)\end{array}$ & $\begin{array}{l}-0.000406 \\
(0.000292)\end{array}$ & $\begin{array}{l}-0.000293 \\
(0.000650)\end{array}$ & $\begin{array}{l}-0.000232 \\
(0.000257)\end{array}$ \\
\hline Stability & - & - & - & - & - & - & - & - & - & - & $\begin{array}{c}-0.000105 \\
(0.00810) \\
\end{array}$ & $\begin{array}{c}0.0227 \\
(0.0319)\end{array}$ \\
\hline Constant & $\begin{array}{l}8.055^{* * *} \\
(1.092)\end{array}$ & $\begin{array}{l}10.35^{* * *} \\
(2.157)\end{array}$ & $\begin{array}{l}6.436^{* * *} \\
(1.862)\end{array}$ & $\begin{array}{c}4.990 \\
(5.523)\end{array}$ & $\begin{array}{l}6.587^{* * *} \\
(1.855)\end{array}$ & $\begin{array}{c}4.813 \\
(5.840)\end{array}$ & $\begin{array}{l}6.745^{* * *} \\
(1.833)\end{array}$ & $\begin{array}{c}5.949 \\
(5.610)\end{array}$ & $\begin{array}{l}6.763^{* * *} \\
(1.833)\end{array}$ & $\begin{array}{c}6.398 \\
(5.819)\end{array}$ & $\begin{array}{l}6.474^{* * *} \\
(1.847)\end{array}$ & $\begin{array}{c}5.273 \\
(5.688)\end{array}$ \\
\hline Observations & 418 & 246 & 418 & 246 & 418 & 246 & 418 & 246 & 418 & 246 & 418 & 246 \\
\hline Number of id & 60 & 42 & 60 & 42 & 60 & 42 & 60 & 42 & 60 & 42 & 60 & 42 \\
\hline
\end{tabular}

Robust standard errors are in brackets. ${ }^{* * *}, * *$ and ${ }^{*}$ indicate statistical significance at the $1 \%, 5 \%$ and $10 \%$ level, respectively.

Note: Here, financial development threshold level is created by using median values of "Private credit by deposit money banks to GDP" in a given year.

Source: Authors' calculations. 
Table 12: GMM estimates on sophistication of exports for more educated and less educated countries where educational level indicator is "tertiary school enrollment": alternative robustness check

\begin{tabular}{|c|c|c|c|c|c|c|c|c|c|c|c|c|}
\hline & (1) & (2) & (3) & (4) & (5) & (6) & (7) & (8) & (9) & (10) & (11) & (12) \\
\hline & $\begin{array}{c}\text { More } \\
\text { Educated }\end{array}$ & $\begin{array}{c}\text { Less } \\
\text { Educated } \\
\end{array}$ & $\begin{array}{c}\text { More } \\
\text { Educated }\end{array}$ & $\begin{array}{c}\text { Less } \\
\text { Educated }\end{array}$ & $\begin{array}{c}\text { More } \\
\text { Educated }\end{array}$ & $\begin{array}{c}\text { Less } \\
\text { Educated }\end{array}$ & $\begin{array}{c}\text { More } \\
\text { Educated }\end{array}$ & $\begin{array}{c}\text { Less } \\
\text { Educated }\end{array}$ & $\begin{array}{c}\text { More } \\
\text { Educated }\end{array}$ & $\begin{array}{c}\text { Less } \\
\text { Educated }\end{array}$ & $\begin{array}{c}\text { More } \\
\text { Educated }\end{array}$ & $\begin{array}{c}\text { Less } \\
\text { Educated }\end{array}$ \\
\hline L.Sophex & $\begin{array}{l}0.3900^{* * *} \\
(0.1210)\end{array}$ & $\begin{array}{c}-0.1390 * \\
(0.0817)\end{array}$ & $\begin{array}{l}0.3690^{* * *} \\
(0.1120)\end{array}$ & $\begin{array}{c}-0.1270 \\
(0.0848)\end{array}$ & $\begin{array}{l}0.3560^{* * *} \\
(0.1150)\end{array}$ & $\begin{array}{l}-0.1220 \\
(0.0819)\end{array}$ & $\begin{array}{l}0.3660^{* * *} \\
(0.1110) \\
\end{array}$ & $\begin{array}{l}-0.1260 \\
(0.0856)\end{array}$ & $\begin{array}{l}0.3900^{* * *} \\
(0.1130)\end{array}$ & $\begin{array}{l}-0.1270 \\
(0.0854)\end{array}$ & $\begin{array}{l}0.3910^{* * *} \\
(0.1150)\end{array}$ & $\begin{array}{c}-0.1230 * \\
(0.0706)\end{array}$ \\
\hline L.GDP & $\begin{array}{l}-0.0190 \\
(0.0197) \\
\end{array}$ & $\begin{array}{l}-0.0348 \\
(0.0962) \\
\end{array}$ & $\begin{array}{l}-0.0095 \\
(0.0176) \\
\end{array}$ & $\begin{array}{l}-0.0986 \\
(0.0820) \\
\end{array}$ & $\begin{array}{l}-0.0170 \\
(0.0157) \\
\end{array}$ & $\begin{array}{l}-0.1060^{*} \\
(0.0642)\end{array}$ & $\begin{array}{l}-0.0104 \\
(0.0175) \\
\end{array}$ & $\begin{array}{l}-0.0695 \\
(0.0596) \\
\end{array}$ & $\begin{array}{l}-0.0111 \\
(0.0171) \\
\end{array}$ & $\begin{array}{l}-0.0651 \\
(0.0575) \\
\end{array}$ & $\begin{array}{l}-0.0084 \\
(0.0175) \\
\end{array}$ & $\begin{array}{l}-0.0857 \\
(0.0685) \\
\end{array}$ \\
\hline L.Patent & $\begin{array}{c}0.0074 \\
(0.0060)\end{array}$ & $\begin{array}{l}\mathbf{0 . 0 2 9 7} \text { * } \\
(0.0176)\end{array}$ & $\begin{array}{c}0.0069 \\
(0.0058)\end{array}$ & $\begin{array}{l}\mathbf{0 . 0 2 9 2} * \\
(0.0166)\end{array}$ & $\begin{array}{c}0.0072 \\
(0.0058)\end{array}$ & $\begin{array}{l}\mathbf{0 . 0 2 8 2}^{*} \\
(0.0168)\end{array}$ & $\begin{array}{c}0.0075 \\
(0.0059)\end{array}$ & $\begin{array}{l}\text { 0.0306* } \\
(0.0181)\end{array}$ & $\begin{array}{c}0.0073 \\
(0.0059)\end{array}$ & $\begin{array}{l}\text { 0.0311* } \\
(0.0174)\end{array}$ & $\begin{array}{c}0.0067 \\
(0.0059)\end{array}$ & $\begin{array}{l}\mathbf{0 . 0 2 9 7 *} \\
(0.0155)\end{array}$ \\
\hline L.FDI & $\begin{array}{c}0.0015 \\
(0.0010)\end{array}$ & $\begin{array}{l}-0.0033 \\
(0.0087)\end{array}$ & $\begin{array}{c}0.0013 \\
(0.0009)\end{array}$ & $\begin{array}{l}-0.0058 \\
(0.0085)\end{array}$ & $\begin{array}{l}0.0015^{*} \\
(0.0008)\end{array}$ & $\begin{array}{l}-0.0045 \\
(0.0082)\end{array}$ & $\begin{array}{c}0.0013 \\
(0.0009)\end{array}$ & $\begin{array}{l}-0.0048 \\
(0.0075)\end{array}$ & $\begin{array}{c}0.0014 \\
(0.0009)\end{array}$ & $\begin{array}{l}-0.0050 \\
(0.0076)\end{array}$ & $\begin{array}{c}0.0014 \\
(0.0009)\end{array}$ & $\begin{array}{l}-0.0067 \\
(0.0103)\end{array}$ \\
\hline L2.FDI & $\begin{array}{l}\mathbf{0 . 0 0 4 2 * * *} \\
(0.0015) \\
\end{array}$ & $\begin{array}{c}-\mathbf{0 . 0 2 1 0} * \\
(0.0110) \\
\end{array}$ & $\begin{array}{l}\mathbf{0 . 0 0 4 1 * * *} \\
(0.0014) \\
\end{array}$ & $\begin{array}{c}-\mathbf{0 . 0 2 3 4} * \\
(0.0121) \\
\end{array}$ & $\begin{array}{l}\mathbf{0 . 0 0 4 2 * * *} \\
(0.0014) \\
\end{array}$ & $\begin{array}{c}-\mathbf{0 . 0 2 2 1 *} \\
(0.0127) \\
\end{array}$ & $\begin{array}{l}\mathbf{0 . 0 0 4 0 * * *} \\
(0.0015) \\
\end{array}$ & $\begin{array}{c}-\mathbf{0 . 0 2 4 3 *} \\
(0.0126) \\
\end{array}$ & $\begin{array}{l}\mathbf{0 . 0 0 4 0 * * *} \\
(0.0015) \\
\end{array}$ & $\begin{array}{c}-0.0244^{*} \\
(0.0126) \\
\end{array}$ & $\begin{array}{l}\mathbf{0 . 0 0 4 0 * * *} \\
(0.0014) \\
\end{array}$ & $\begin{array}{c}-\mathbf{0 . 0 2 4 1} * \\
(0.0129) \\
\end{array}$ \\
\hline Saving & $\begin{array}{c}0.0102^{* * *} \\
(0.0035)\end{array}$ & $\begin{array}{c}0.0428 \\
(0.0376)\end{array}$ & $\begin{array}{l}0.0092^{* * *} \\
(0.0031)\end{array}$ & $\begin{array}{c}0.0482 \\
(0.0361)\end{array}$ & $\begin{array}{l}0.0087^{* * *} \\
(0.0031)\end{array}$ & $\begin{array}{c}0.0462 \\
(0.0359)\end{array}$ & $\begin{array}{l}0.0090^{* * *} \\
(0.0030)\end{array}$ & $\begin{array}{c}0.0475 \\
(0.0351)\end{array}$ & $\begin{array}{l}0.0105^{* * *} \\
(0.0031)\end{array}$ & $\begin{array}{c}0.0470 \\
(0.0358)\end{array}$ & $\begin{array}{c}0.0105^{* * *} \\
(0.0033)\end{array}$ & $\begin{array}{c}0.0484 \\
(0.0400)\end{array}$ \\
\hline Population & - & - & $\begin{array}{c}-0.1210 \\
(0.0890)\end{array}$ & $\begin{array}{c}0.3530 \\
(0.3420) \\
\end{array}$ & $\begin{array}{l}-0.1230 \\
(0.0853) \\
\end{array}$ & $\begin{array}{l}0.3930 \\
(0.470)\end{array}$ & $\begin{array}{c}-0.1220 \\
(0.0869) \\
\end{array}$ & $\begin{array}{c}0.2850 \\
(0.3770)\end{array}$ & $\begin{array}{l}-0.1230 \\
(0.0850) \\
\end{array}$ & $\begin{array}{c}0.2620 \\
(0.3730) \\
\end{array}$ & $\begin{array}{l}-0.1220 \\
(0.0872) \\
\end{array}$ & $\begin{array}{c}0.3070 \\
(0.4190) \\
\end{array}$ \\
\hline Law & - & - & - & - & $\begin{array}{c}0.0260 \\
(0.0193) \\
\end{array}$ & $\begin{array}{c}0.0212 \\
(0.1330) \\
\end{array}$ & - & - & - & - & - & - \\
\hline Regulatory & - & - & - & - & - & - & $\begin{array}{c}0.0077 \\
(0.0106) \\
\end{array}$ & $\begin{array}{l}-0.0571 \\
(0.0971) \\
\end{array}$ & $\begin{array}{c}0.0071 \\
(0.0106) \\
\end{array}$ & $\begin{array}{l}-0.0576 \\
(0.0974) \\
\end{array}$ & - & - \\
\hline Deflator & - & - & - & - & - & - & - & - & $\begin{array}{l}-0.0004^{* * *} \\
(0.0001) \\
\end{array}$ & $\begin{array}{l}-0.0003 \\
(0.0006)\end{array}$ & $\begin{array}{c}-0.0003^{* *} \\
(0.0001) \\
\end{array}$ & $\begin{array}{l}-0.0002 \\
(0.0006)\end{array}$ \\
\hline Stability & - & - & - & - & - & - & - & - & - & - & $\begin{array}{l}-0.0053 \\
(0.0074) \\
\end{array}$ & $\begin{array}{l}-0.0115 \\
(0.0601) \\
\end{array}$ \\
\hline Constant & $\begin{array}{l}6.1400^{* * *} \\
(1.0990)\end{array}$ & $\begin{array}{l}11.1600 * * * \\
(1.4570)\end{array}$ & $\begin{array}{l}8.2530^{* * *} \\
(1.5930)\end{array}$ & $\begin{array}{c}5.3930 \\
(6.4460) \\
\end{array}$ & $\begin{array}{l}8.4700^{* * *} \\
(1.5100)\end{array}$ & $\begin{array}{c}4.7300 \\
(8.7120) \\
\end{array}$ & $\begin{array}{l}8.2940^{* * *} \\
(1.6090)\end{array}$ & $\begin{array}{c}6.3150 \\
(7.0670) \\
\end{array}$ & $\begin{array}{l}8.0780^{* * *} \\
(1.6110)\end{array}$ & $\begin{array}{c}6.6970 \\
(6.9630) \\
\end{array}$ & $\begin{array}{l}8.0360^{* * *} \\
(1.5920)\end{array}$ & $\begin{array}{c}6.0490 \\
(7.5340)\end{array}$ \\
\hline Observations & 325 & 191 & 325 & 191 & 325 & 191 & 325 & 191 & 325 & 191 & 325 & 191 \\
\hline Number of id & 50 & 38 & 50 & 38 & 50 & 38 & 50 & 38 & 50 & 38 & 50 & 38 \\
\hline
\end{tabular}

Note: Robust standard errors are in brackets. ${ }^{* * *},{ }^{* *}$ and ${ }^{*}$ indicate statistical significance at the $1 \%, 5 \%$ and $10 \%$ level, respectively.

Here, education threshold level is created by using median values of "tertiary school enrolment" in a given year.

Source: Authors' calculations. 
Table 13: GMM estimates on sophistication of exports for more globalized and less globalized countries: alternative robustness check

\begin{tabular}{|c|c|c|c|c|c|c|c|c|c|c|c|c|}
\hline & (1) & (2) & (3) & (4) & (5) & (6) & (7) & (8) & (9) & (10) & $(11)$ & $(12)$ \\
\hline & $\begin{array}{c}\text { More } \\
\text { Globalized }\end{array}$ & $\begin{array}{c}\text { Less } \\
\text { Globalized }\end{array}$ & $\begin{array}{c}\text { More } \\
\text { Globalized }\end{array}$ & $\begin{array}{c}\text { Less } \\
\text { Globalized }\end{array}$ & $\begin{array}{c}\text { More } \\
\text { Globalized }\end{array}$ & $\begin{array}{c}\text { Less } \\
\text { Globalized }\end{array}$ & $\begin{array}{c}\text { More } \\
\text { Globalized }\end{array}$ & $\begin{array}{c}\text { Less } \\
\text { Globalized }\end{array}$ & $\begin{array}{c}\text { More } \\
\text { Globalized }\end{array}$ & $\begin{array}{c}\text { Less } \\
\text { Globalized }\end{array}$ & $\begin{array}{c}\text { More } \\
\text { Globalized }\end{array}$ & $\begin{array}{c}\text { Less } \\
\text { Globalized }\end{array}$ \\
\hline L.Sophex & $\begin{array}{c}0.1760^{* *} \\
(0.0865) \\
\end{array}$ & $\begin{array}{c}-0.0441 \\
(0.1730) \\
\end{array}$ & $\begin{array}{l}0.1560^{*} \\
(0.0914) \\
\end{array}$ & $\begin{array}{r}-0.0465 \\
(0.1590) \\
\end{array}$ & $\begin{array}{l}0.1560^{*} \\
(0.0910) \\
\end{array}$ & $\begin{array}{l}-0.0510 \\
(0.1460) \\
\end{array}$ & $\begin{array}{c}0.1480 \\
(0.0938) \\
\end{array}$ & $\begin{array}{r}-0.0488 \\
(0.1590) \\
\end{array}$ & $\begin{array}{c}0.1540 \\
(0.0961) \\
\end{array}$ & $\begin{array}{c}-0.0481 \\
(0.1610) \\
\end{array}$ & $\begin{array}{l}0.1620^{*} \\
(0.0921) \\
\end{array}$ & $\begin{array}{r}-0.0524 \\
(0.1530) \\
\end{array}$ \\
\hline L.GDP & $\begin{array}{l}-0.0037 \\
(0.0252)\end{array}$ & $\begin{array}{c}0.0124 \\
(0.0942)\end{array}$ & $\begin{array}{l}-0.0259 \\
(0.0249)\end{array}$ & $\begin{array}{l}-0.0802 \\
(0.0725)\end{array}$ & $\begin{array}{l}-0.0337 \\
(0.0243)\end{array}$ & $\begin{array}{l}-0.0838 \\
(0.0679)\end{array}$ & $\begin{array}{l}-0.0274 \\
(0.0254)\end{array}$ & $\begin{array}{l}-0.0477 \\
(0.0646)\end{array}$ & $\begin{array}{l}-0.0280 \\
(0.0246)\end{array}$ & $\begin{array}{l}-0.0439 \\
(0.0648)\end{array}$ & $\begin{array}{l}-0.0265 \\
(0.0247)\end{array}$ & $\begin{array}{l}-0.0906 \\
(0.0729)\end{array}$ \\
\hline L.Patent & $\begin{array}{l}\mathbf{0 . 0 2 1 9} * * * \\
(0.0071)\end{array}$ & $\begin{array}{l}\mathbf{0 . 0 2 5 0} \\
(0.0168) \\
\end{array}$ & $\begin{array}{l}\mathbf{0 . 0 2 0 8} * * * \\
(0.0069) \\
\end{array}$ & $\begin{array}{l}\mathbf{0 . 0 2 5 2}^{*} \\
(0.0151)\end{array}$ & $\begin{array}{l}\mathbf{0 . 0 2 1 3} * * * \\
(0.0067) \\
\end{array}$ & $\begin{array}{c}\mathbf{0 . 0 2 4 1} \\
(0.0163) \\
\end{array}$ & $\begin{array}{l}\mathbf{0 . 0 2 1 5} * * * \\
(0.0070) \\
\end{array}$ & $\begin{array}{l}\mathbf{0 . 0 2 6 3 *} \\
(0.0156) \\
\end{array}$ & $\begin{array}{l}\mathbf{0 . 0 2 1 6 * * *} \\
(0.0070) \\
\end{array}$ & $\begin{array}{l}\mathbf{0 . 0 2 6 8 *} \\
(0.0162) \\
\end{array}$ & $\begin{array}{l}\mathbf{0 . 0 2 0 9} * * * \\
(0.0068) \\
\end{array}$ & $\begin{array}{l}\mathbf{0 . 0 2 6 1 *} \\
(0.0157)\end{array}$ \\
\hline L.FDI & $\begin{array}{c}0.0009 \\
(0.0011) \\
\end{array}$ & $\begin{array}{l}-0.0136 \\
(0.0125) \\
\end{array}$ & $\begin{array}{c}0.0014 \\
(0.0011) \\
\end{array}$ & $\begin{array}{l}-0.0160 \\
(0.0128) \\
\end{array}$ & $\begin{array}{c}0.0016 \\
(0.0010) \\
\end{array}$ & $\begin{array}{c}-0.0158 \\
(0.0123) \\
\end{array}$ & $\begin{array}{c}0.0014 \\
(0.0011) \\
\end{array}$ & $\begin{array}{c}-0.0139 \\
(0.0112) \\
\end{array}$ & $\begin{array}{c}0.0014 \\
(0.0010)\end{array}$ & $\begin{array}{c}-0.0140 \\
(0.0113)\end{array}$ & $\begin{array}{c}0.0015 \\
(0.0011) \\
\end{array}$ & $\begin{array}{c}-0.0158 \\
(0.0132)\end{array}$ \\
\hline L2.FDI & $\begin{array}{l}\mathbf{0 . 0 0 2 7} * \\
(0.0015)\end{array}$ & $\begin{array}{c}-0.0323^{* *} \\
(0.0136)\end{array}$ & $\begin{array}{l}\mathbf{0 . 0 0 2 9} * * \\
(0.0014)\end{array}$ & $\begin{array}{c}-\mathbf{0 . 0 3 7 1 * *} \\
(0.0145) \\
\end{array}$ & $\begin{array}{l}\mathbf{0 . 0 0 3 0} \text { ** } \\
(0.0014)\end{array}$ & $\begin{array}{c}-\mathbf{0 . 0 3 5 5 ^ { * * }} \\
(0.0150) \\
\end{array}$ & $\begin{array}{l}\mathbf{0 . 0 0 2 8} * \\
(0.0015)\end{array}$ & $\begin{array}{c}-0.0367^{* * *} \\
(0.0140) \\
\end{array}$ & $\begin{array}{c}\mathbf{0 . 0 0 2 9} * \\
(0.0015)\end{array}$ & $\begin{array}{c}-0.0371 * * * \\
(0.0143) \\
\end{array}$ & $\begin{array}{l}\mathbf{0 . 0 0 2 9} \text { ** } \\
(0.0014) \\
\end{array}$ & $\begin{array}{c}-0.0357^{* *} \\
(0.0143) \\
\end{array}$ \\
\hline Saving & $\begin{array}{c}0.0094 \\
(0.0061) \\
\end{array}$ & $\begin{array}{c}0.0330 \\
(0.0322) \\
\end{array}$ & $\begin{array}{c}0.0099 * \\
(0.0054) \\
\end{array}$ & $\begin{array}{c}0.0367 \\
(0.0305) \\
\end{array}$ & $\begin{array}{c}0.0101^{*} \\
(0.0056) \\
\end{array}$ & $\begin{array}{c}0.0358 \\
(0.0313) \\
\end{array}$ & $\begin{array}{c}0.0098^{*} \\
(0.0055) \\
\end{array}$ & \begin{tabular}{c|}
0.0353 \\
$(0.0292)$ \\
\end{tabular} & $\begin{array}{c}0.0100 * * \\
(0.0045) \\
\end{array}$ & $\begin{array}{c}0.0361 \\
(0.0302) \\
\end{array}$ & $\begin{array}{c}0.0100^{* *} \\
(0.0045) \\
\end{array}$ & $\begin{array}{c}0.0352 \\
(0.0330) \\
\end{array}$ \\
\hline Population & - & - & $\begin{array}{c}0.1310 \\
(0.1010) \\
\end{array}$ & $\begin{array}{c}0.4340 \\
(0.2990) \\
\end{array}$ & $\begin{array}{c}0.1310 \\
(0.0994)\end{array}$ & $\begin{array}{c}0.4640 \\
(0.3250)\end{array}$ & $\begin{array}{c}0.1240 \\
(0.0986)\end{array}$ & $\begin{array}{c}0.3460 \\
(0.3360) \\
\end{array}$ & $\begin{array}{c}0.1110 \\
(0.1010) \\
\end{array}$ & $\begin{array}{c}0.3240 \\
(0.3540)\end{array}$ & $\begin{array}{c}0.1170 \\
(0.1040) \\
\end{array}$ & $\begin{array}{c}0.4380 \\
(0.3250)\end{array}$ \\
\hline Law & - & - & - & - & $\begin{array}{c}0.0217 \\
(0.0228) \\
\end{array}$ & $\begin{array}{c}0.0458 \\
(0.0728) \\
\end{array}$ & - & - & - & - & - & - \\
\hline Regulatory & - & - & - & - & - & - & $\begin{array}{c}0.0104 \\
(0.0105) \\
\end{array}$ & $\begin{array}{l}-0.0612 \\
(0.0804) \\
\end{array}$ & $\begin{array}{c}0.0086 \\
(0.0106) \\
\end{array}$ & $\begin{array}{l}-0.0624 \\
(0.0816) \\
\end{array}$ & - & - \\
\hline Deflator & - & - & - & - & - & - & - & - & $\begin{array}{r}-0.0005 \\
(0.0006) \\
\end{array}$ & $\begin{array}{r}-0.0002 \\
(0.0003) \\
\end{array}$ & $\begin{array}{l}-0.0006 \\
(0.0005) \\
\end{array}$ & $\begin{array}{l}-0.0001 \\
(0.0003) \\
\end{array}$ \\
\hline Stability & - & - & - & - & - & - & - & - & - & - & $\begin{array}{c}-0.0059 \\
(0.00859) \\
\end{array}$ & $\begin{array}{c}0.0248 \\
(0.0304)\end{array}$ \\
\hline Constant & $\begin{array}{c}8.0400^{* * *} \\
(0.7970) \\
\end{array}$ & $\begin{array}{c}9.8230^{* * * *} \\
(2.2380) \\
\end{array}$ & $\begin{array}{l}6.2820^{* * *} \\
(1.5430)\end{array}$ & $\begin{array}{c}3.1850 \\
(6.0800) \\
\end{array}$ & $\begin{array}{l}6.3430 * * * \\
(1.5030) \\
\end{array}$ & $\begin{array}{c}2.7610 \\
(6.5060)\end{array}$ & $\begin{array}{c}6.4860^{* * *} \\
(1.5470) \\
\end{array}$ & $\begin{array}{c}4.4040 \\
(6.8010)\end{array}$ & $\begin{array}{l}6.6360^{* * * *} \\
(1.5340)\end{array}$ & $\begin{array}{c}4.7540 \\
(7.1290) \\
\end{array}$ & $\begin{array}{c}6.4660 * * * \\
(1.5530) \\
\end{array}$ & $\begin{array}{c}3.2860 \\
(6.3720) \\
\end{array}$ \\
\hline Observations & 421 & 225 & 421 & 225 & 421 & 225 & 421 & 225 & 421 & 225 & 421 & 225 \\
\hline Number of id & 57 & 39 & 57 & 39 & 57 & 39 & 57 & 39 & 57 & 39 & 57 & 39 \\
\hline
\end{tabular}

Note: Robust standard errors are in brackets. ${ }^{* * *},{ }^{* *}$ and ${ }^{*}$ indicate statistical significance at the $1 \%, 5 \%$ and $10 \%$ level, respectively.

Here, globalization threshold level is created by using median values of "KOF Globalization Index" in a given year.

Source: Authors' calculations. 


\section{References}

Alfaro, L., Chanda, A., Kalemli-Ozcan, S., et al. (2010). Does Foreign Direct Investment Promote Growth? Exploring the Role of Financial Markets on Linkages. Journal of Development Economics, 91(2), 242-256, https://doi.org/10.1016/j.jdeveco.2009.09.004

Ang, J. (2011). Financial Development, Liberalization and Technological Deepening. European Economic Review, 55(5), 688-701, https://doi.org/10.1016/j.euroecorev.2010.09.004

Arellano, M., Stephen, R. B. (1991). Some Tests of Specification for Panel Data: Monte Carlo Evidence and an Application to Employment Equations. Review of Economic Studies, 58(2), 277-297, https://doi.org/10.2307/2297968

Blind, K., Jungmittag, A. (2006). Trade and the Impact of Innovations and Standards: The Case of Germany and the UK. Applied Economics, 37(12), 1385-1398, https://doi.org/10.1080/13504850500143294

Bond, S. R. (2002). Dynamic Panel Data Models: A Guide to Micro Data Methods and Practice. Centre for Microdata Methods and Practice. London Working Paper No. CWP09/02, http://doi.org/10.1920/wp.cem.2002.0902

Borensztein, E., De Gregorio, J., Lee, J. W. (1998). How Does Foreign Direct Investment Affect Economic Growth? Journal of international Economics, 45(1), 115-135, https://doi.org/10.1016/S0022-1996(97)00033-0

Chang, C. L., Chen, S. P., McAleer, M. (2013). Globalization and Knowledge Spillover: International Direct Investment, Exports and Patents. Economics of Innovation and New Technology, 22(4), 329-352, https://doi.org/10.1080/10438599.2012.707412

Chuang, Y.-C., Lin, C.-M. (1999). Foreign Direct Investment, R\&D and Spillover Efficiency: Evidence from Taiwan's Manufacturing Firms. Journal of Development Studies, 35(4), 117-137, https://doi.org/10.1080/00220389908422583

Coe, D. T., Helpman, E. (1995). International R\&D spillovers. European Economic Review, 39(5), 859-887, https://doi.org/10.1016/0014-2921(94)00100-E

Cohen, W. M., Levinthal, D. A. (1990). Absorptive Capacity: A New Perspective on Learning and Innovation. Administrative Science Quarterly, 35(1), 128-152, https://doi.org/10.2307/2393553

Fajgelbaum, P., Grossman, G. M., Helpman, E. (2015). A Linder Hypothesis for Foreign Direct Investment. The Review of Economic Studies, 82(1), 83-121, https://doi.org/10.1093/ restud/rdu027

Findlay, R. (1978). Relative Backwardness, Direct Foreign Investment, and the Transfer of Technology: A Simple Dynamic Model. Quarterly Journal of Economics, 92(1), 1-16, https://doi.org/10.2307/1885996

Fracasso, A., Marzetti, G. V. (2015). International Trade and R\&D Spillovers. Journal of International Economics, 96(1), 138-149, https://doi.org/10.1016/j.jinteco.2015.01.010

Girma, S. (2005). Absorptive Capacity and Productivity Spillovers from FDI: A Threshold Regression Analysis. Oxford Bulletin of Economics and Statistics, 67(3), 281-306, https://doi.org/10.1111/j.1468-0084.2005.00120.x 
Grossman, G. M., Helpman, E. (2015). Globalization and Growth. American Economic Review, 105(5), 100-104, http://doi.org/10.1257/aer.p20151068

Haddad, M., Harrison, A. (1993). Are there Positive Spillovers from Direct Foreign Investment? Evidence from Panel Data for Morocco. Journal of Development Economics, 42(1), 51-74, https://doi.org/10.1016/0304-3878(93)90072-U

Hausmann, R., Hwang, J., Rodrik, D. (2007). What you Export Matters. Journal of Economic Growth, 12(1), 1-25, https://doi.org/10.1007/s10887-006-9009-4

Hausmann, R., Hidalgo, C. A., Bustos, S., et al. (2014). The Atlas of Economic Complexity; Mapping Paths to Prosperity. Section 3. Available at: http://atlas.cid.harvard.edu/

Hermes, N., Lensik, R. (2003). Foreign Direct Investment, Financial Development and Economic Growth. Journal of Development Studies, 40(1), 142-163, http://doi.org/ 10.1080/00220380412331293707

Hidalgo, C. A., Klinger, B., Barabasi, A-L., et al. (2007). The Product Space Conditions the Development of Nations. Science, 317(5837), 482-487, https://doi.org/10.1126/ science. 1144581

Hidalgo, C. A., Hausmann, R. (2009). The Building Blocks of Economic Complexity. Proceedings of the National Academy of Science of the United States of America, 106(26), 10570-10575, https://doi.org/10.1073/pnas.0900943106

Hu, A. G. Z., Jefferson, G. H., Guan, X., et al. (2003). R\&D and Technology Transfer: Firm-level Evidence from Chinese Industry. William Davidson Institute. Ann Arbor, Michigan Working Paper No. 582, https://doi.org/10.2139/ssrn.578241

Huang, S., Chen, Y. (2014). FDI in Services and China's Service Export Sophistication. In 201411 th International Conference on Service Systems and Service Management (ICSSSM), pp. 1-5, https://doi.org/10.1109/ICSSSM.2014.6874085

Ivus, O. (2010). Do Stronger Patent Rights Raise High-tech Exports to the Developing World? Journal of International Economics, 81(1), 38-47, https://doi.org/10.1016/j. jinteco.2009.12.002

Iwamoto, M., Nabeshima, K. (2012). Can FDI Promote Export Diversification and Sophistication of Host Countries? Dynamic Panel System GMM Analysis. Institute of Developing Economies, Japan External Trade Organization (JETRO). Discussion Papers No. 347. Available at: https://ideas.repec.org/p/jet/dpaper/dpaper347.html

Jaffe, A., Trajtenberg, M. (1999). International Knowledge Flows: Evidence from Patent Citations. Economics of Innovation and New Technology, 8(1-2), 105-136, https://doi.org/10.1080/10438599900000006

Jaimovich, E., Vincenzo, M. (2012). Quality Ladders in a Ricardian Model of Trade with Nonhomothetic Preferences. Journal of the European Economic Association, 10(4), 908-937, https://doi.org/10.1111/j.1542-4774.2012.01077.x

Jaimovich, E., Merella, V. (2015). Love for Quality, Comparative Advantage, and Trade. Journal of International Economics, 97(2), 376-391, https://doi.org/10.1016/j.jinteco.2015.06.004 
Jarreau, J., Poncet, S. (2012). Export Sophistication and Economic Growth: Evidence from China. Journal of Development Economics, 97(2), 281-292, https://doi.org/10.1016/j. jdeveco.2011.04.001

Kemeny, T. (2010). Does Foreign Direct Investment Drive Technological Upgrading? World Development, 38(11), 1543-1554, https://doi.org/10.1016/j.worlddev.2010.03.001

Kostevc, Č. (2005). Performance of Exporters: Scale Effects or Continuous Productivity Improvements. LICOS Centre for Transition Economics. Leuven Discussion Paper No. 159/2005, https://doi.org/10.2139/ssrn.881527

Lall, S., Weiss, J., Zhang, J. (2006). The "Sophistication" of Exports: a New Trade Measure. World Development, 34(2), 222-237, https://doi.org/10.1016/j.worlddev.2005.09.002

Leitão, N. C. (2012). Foreign Direct Investment and Globalization. Munich Personal RePEc Archive. Munich MPRA Paper No. 37436. Available at: https://mpra.ub.uni-muenchen. de/37436/

León-Ledesma, M. A. (2005). Exports, Product Differentiation and Knowledge Spillovers. Open Economies Review, 16(4), 363-379, https://doi.org/10.1007/s11079-005-4740-6

Liu, Z. (2008). Foreign Direct Investment and Technology Spillovers: Theory and Evidence. Journal of Development Economics, 85(1), 176-193, https://doi.org/10.1016/j. jdeveco.2006.07.001

Lu, Y., Tao, Z., Zhu, L. (2017). Identifying FDI Spillovers. Journal of International Economics, 107, 75-90, https://doi.org/10.1016/j.jinteco.2017.01.006

Meo, S. A., Usmani, A. M. (2014). Impact of R\&D Expenditures on Research Publications, Patents and High-tech Exports Among European Countries. European Review for Medical and Pharmacological Sciences, 18(1), 1-9. Available at: https://www.europeanreview.org/ article/6438

Minondo, A. (2010). Exports' Quality-adjusted Productivity and Economic Growth. Journal of International Trade \& Economic Development, 19(2), 257-287, https://doi.org/10.1080/09638190802573071

Newman, C., Rand, J., Talbot, T., et al. (2015). Technology Transfers, Foreign Investment and Productivity Spillovers. European Economic Review, 76, 168-187, https://doi.org/10.1016/j.euroecorev.2015.02.005

OECD (2001). OECD Global Forum on International Investment New Horizons for Foreign Direct Investment. Paris: OECD.

Potrafke, N. (2015). The Evidence on Globalization. The World Economy, 38(3), 509-552, https://doi.org/10.1111/twec.12174

Rajan, R. G., Zingales, L. (1998). Financial Dependence and Growth. The American Economic Review, 88(3), 559-586, https://doi.org/10.3386/w5758

Roodman, D. (2006). How to do Xtabond2: An Introduction to Difference and System GMM in Stata. Center for Global Development. Working Paper No. 103, https://doi.org/10.2139/ssrn.982943 
Sargan, J. D. (1958). The Estimation of Economic Relationships using Instrumental Variables. Econometrica, 26(3), 393-415, https://doi.org/10.2307/1907619

Xu, B., Lu, J. (2009). Foreign Direct Investment, Processing Trade, and the Sophistication of China's Exports. China Economic Review, 20(3), 425-439, https://doi.org/10.1016/j. chieco.2009.01.004

Yu, C., Hu, X. (2015). Sophistication of China's Manufactured Exports and Determinants. Transnational Corporations Review, 7(2), 169-189, https://doi.org/10.5148/tncr.2015.7204

Zhang, Y., Cheng, Z., He, Q. (2019). Time Lag Analysis of FDI Spillover Effect. International Journal of Emerging Markets, 15(4), 629-650, https://doi.org/10.1108/ ijoem-03-2019-0225

Zhu, S., Fu, X. (2013). Drivers of Export Upgrading. World Development, 51(11), 221-233, https://doi.org/10.1016/j.worlddev.2013.05.017 